OPEN ACCESS

Edited by:

Andrea Pieroni,

University of Gastronomic

Sciences, Italy

Reviewed by:

Rainer Willi Bussmann,

llia State University, Georgia

Pashupati Chaudhary

International Centre for Integrated

Mountain Development, Nepal

*Correspondence:

Francesca Castagnetti francesca@hearthalliance.org

Specialty section:

This article was submitted to Social Movements, Institutions and

Governance,

a section of the journal

Frontiers in Sustainable Food Systems

Received: 28 December 2020

Accepted: 26 February 2021

Published: 30 March 2021

Citation:

Castagnetti F, Bhatta J and Greene A (2021) An Offering of Grain: The Agricultural and Spiritual Cycle of a Food System in the Kailash Sacred Landscape, Darchula, Far Western

\section{An Offering of Grain: The Agricultural and Spiritual Cycle of a Food System in the Kailash Sacred Landscape, Darchula, Far Western Nepal}

\author{
Francesca Castagnetti ${ }^{1,2 *}$, Jagdish Bhatta ${ }^{3}$ and Alexander Greene ${ }^{1,2,4}$ \\ ${ }^{1}$ Hearth: The Healing Earth Alliance, Edinburgh, United Kingdom, ${ }^{2}$ Centre for Biocultural Diversity, School of Anthropology \\ and Conservation, University of Kent, Canterbury, United Kingdom, ${ }^{3}$ Department of Plant Breeding and Genetics, Agriculture \\ and Forestry University, Rampur, Nepal, ${ }^{4}$ Le laboratoire Ecologie, Evolution, Interactions des Systèmes amazoniens, \\ University of French Guiana, Cayenne, France
}

Foodscapes are commonly embedded in spiritual landscapes, making the spiritual dimension of local and indigenous food systems an important element of food sovereignty. However, this dimension is often overlooked in food systems research and policy making. Based on ethnobiological fieldwork conducted in the Kailash Sacred Landscape of far western Nepal, we show how religious festivals and rituals reenact the covenant between people and the land through the numinous intercession of Hindu gods and landscape deities. To demonstrate this, we present the local calendar of the agricultural and ritual year based on data collected through household surveys and participation in festivals and agricultural activities. The complex fabric of the local agri-food system is revealed as articulated in the warp and weft of interwoven agricultural and spiritual cycles. These cycles contribute to respectful and sustainable landscape management practices by shaping the relationship people have with the land. In the annual women's festival of Gaura, the fertility and well-being of people and land is affirmed through the offering of locally produced pulses and grains. Furthermore, local gastronomic identity is enriched by the incentive to cultivate heirloom varieties of crops that are prescribed in rituals performed during Gaura and other major festivals. We conclude that spiritual practices should be considered key elements of biocultural diversity, and recommend that they receive more attention in the implementation of sustainable development that aims to embody the principles of food sovereignty.

Keywords: food sovereignty, agri-food system, agro-spiritual calendar, traditional knowledge, biocultural diversity, agricultural ritual, sacred landscape, agro-spiritual cycle

\section{INTRODUCTION}

Local and indigenous food systems in rural areas have long been contested spaces where interests are negotiated by different actors with often conflicting agendas. The stakes of research and development involving traditional and local knowledge, including Traditional Food Knowledge, are high. Kimmerer (2012) has vividly expressed a concern about knowledge mining that we, as researchers, are acutely aware of: "knowledge mining or the extraction of useful facts from the body of knowledge, without exploration of the cultural context in which they belong, can do a disservice 
to the information as well as to the culture. Just as gold mining degrades a large area of land for the extraction of what is perceived as valuable "ore" and leaves a wasteland in its place, extraction of valuable data from traditional knowledge without consideration of its cultural context can also be damaging." A general disconnect between top-down development and management, and local and indigenous relations to their lands, tends to "persist in ways that erode even the best attempts at collaborative management and plans for long-term sustainability in our contemporary plural societies," Felice Wyndham has observed (Wyndham, 2009). Li (2007) has exposed how organizations' "claim to expertise in optimizing the lives of others is a claim to power." Co-management has often had the effect of, at best involuntarily, forcing rural and indigenous communities into tacitly accepting assumptions about the nature of the land and the species to be managed, with state institutions failing to understand local values and worldviews (Nadasdy, 2005), and thus imposing the institution-held scientific assumptions rather than engaging in cross-cultural co-construction of knowledge (Apgar et al., 2016).

Food sovereignty has increasingly been adopted by civil society organizations and global social movements as a tool for contestation, reconfiguration and metamorphosis (Pimbert, 2006; Patel, 2007, 2009; Van der Ploeg, 2008, 2010; RiveraFerre, 2018). Food sovereignty, as defined in the Declaration of Nyéléni (2007), attests to the right of people to define their own food systems in ways that are empowering, context-dependant and culturally appropriate, prioritizing local and national economies rather than the demands of the corporate trade market. The Declaration was crafted by local and Indigenous communities from all over the world who demanded to place at the heart of food systems policy the very people and communities who produce, distribute and consume food.

Conversely, the top-down scholarly and policy making framework of food security, as suggested by Patel, "is agnostic about the production regime, about the social and economic conditions under which food ends up on the table" (Patel, 2007). Food security oriented policy is rooted in the narrative of food scarcity, and it has occasionally provided a justification to the narrative of terra nullius - empty land (Harvey, 2007; White et al., 2012), which has historically legitimized land expropriation and all sorts of abuse on indigenous territories around the world (Coates, 2004). Policy framed uniquely by a concern for food security may tend to prioritize quantity over quality, and to overlook discourses on modes of production and distribution, alongside their impact on local and global social dynamics. The discipline of political ecology is well-suited for agri-food systems research, as it focuses strongly on both social-ecological interactions and political-economic dynamics (Hall, 2015). A political ecology framework invites analysis that attempts to understand "the ways in which food, agriculture, and the environment are understood and valued, and the profound inequalities that underpin the production, transformation, and consumption of food" (Hall, 2015). Quoting Slow Food's slogan, Nabhan (2014) invites a partnership between ethnobiology and political ecology to predict "how we can better design our food systems, not only to be resilient in the face of climate change and other "shocks," but to be "good, clean and fair" as well."

In an ethnobiological approach to food systems, the entire dimension of social-ecological systems is considered, including ecosystems, place-related history, culture, and importantly, the spiritual aspects comprising local diversity (Pieroni et al., 2016). The Declaration of Nyéléni (2007) acknowledges all of these aspects of social-ecological systems, and embraces a view of nature as including both spiritual and material beings. Yet, very little attention in the declaration is directed toward the spiritual landscapes underlying traditional and indigenous food systems. In the reports of the Food and Agriculture Organization (FAO) and the High Level Panel of Experts for Food Security and Nutrition (HLPE), the spiritual dimension is either not mentioned, or touched upon in rather reductive and generic terms by including it among cultural ecosystem services alongside aesthetic, recreational, inspirational and educational benefits (HLPE, 2017; FAO, 2019; FAO and UNEP, 2020). In Nepal, food sovereignty was recognized as a constitutional right in 2064 (Interim Constitution of Nepal 2063, 2007). The right to food sovereignty in Nepal was further defined in the The Right to Food and Food Sovereignty (2018), where the government also commits to protect traditional and indigenous food. Still, in the act no mention is made of the spiritual dimension of traditional and indigenous food.

While the literature discussing food sovereignty and exploring all elements of local and Indigenous food systems, including spirituality, is broad, few works have demonstrated the importance of the sacred domain in food sovereignty, and the role of spiritual beliefs and practices in protecting and contributing to biocultural diversity in sustainable food systems. Rappaport (1968) was among the first scholars to discuss the role of ritual in the Tsembaga's food system in New Guinea as regulators of relationships with animals and plants and conservation of certain species. Barrera-Bassols and Toledo (2005) discuss the complex entanglement of beliefs, knowledge and landscape management by presenting aspects of the Yucatec Mayan spiritual landscape and the sacred dimension as a key contributor to their social-ecological resilience. Håland $(2009,2012,2015)$ has discussed ritual and agricultural yearly cycles by comparing modern and ancient Greek festivals, and illustrated the importance to farmers of fertility magic to ensure good harvests both in modern and ancient Greece. Salmón (1999) shows how the physical, social and mental health of northern Mexico Rarámuri are closely related to their cycle of ceremony. Felice Wyndham further explored Rarámuri landscape management from a relational perspective by discussing what she calls the subtle ecologies of people's relations and interactions with the landscape. She shows how "the subtle material effects of ritual and exchanges with the spirit world" affect the making and unmaking of landscapes over time (Wyndham, 2009). Wyndham also denounces a persisting disjunction between Western management practices and indigenous relations to landscape, and highlights the importance of investigating people-landscape relationality in Western inquiries into indigenous land management. Part of a growing trend for the recognition of food sovereignty as 
a key element in in-situ biodiversity conservation, Sarmiento et al. (2019) present case studies from Andean agri-food systems and highlight the role of the spiritual dimension of indigenous foodscapes in the preservation of heirloom varieties with special spiritual status. Haider et al. (2020) discuss the role of traditional practices and rituals in defining alternative development pathways, and focus on the social-ecological implications of an introduced wheat on the food practices of a New Year ritual in two communities in the Pamir Mountains.

Based on ethnobotanical fieldwork conducted in the village of Malikarjun, in the Kailash Sacred Landscape of far western Nepal, this study contributes to these discourses by revealing the complex fabric of a village agri-food system as articulated in the warp and weft of its interwoven agricultural and spiritual cycles.

\section{METHODOLOGY}

\section{Field Site Description}

Fieldwork centered on the community of Malikarjun, located in Darchula District of far western Nepal. Malikarjun is a small village of around 500 households located $<10 \mathrm{~km}$ from the Mahakali River, which forms the border with India. Malikarjun falls within the Kailash Sacred Landscape (KSL), which encompasses far western Nepal and the neighboring regions of India and China. The International Center for Intermountain Development (ICIMOD) designated the KSL as a critical transboundary landscape in 2010 due to its rich ecological and cultural diversity and heritage (Oli and Zomer, 2010). At the spiritual heart of this landscape is Mt. Kailash in Tibet, a sacred site for millions of Hindus, Buddhists, Sikhs, Bönpos, and Jains (Zomer and Oli, 2011). The entire region comprises an intricate network of spiritual sites, many connected to the ancient pilgrimage routes that center on Mt. Kailash. Malikarjun, located $165 \mathrm{~km}$ south of Mt. Kailash, is the site of its own sacred mountain, which bears the same name as the community.

The community centers on a market and temple, which are located at $1,800 \mathrm{~m}$ on a narrow ridge. The community is distributed along the ridge up to $2,100 \mathrm{~m}$, and down to the small streams that run in the valleys on both sides of the ridge. Other than these streams, located well below the community center, the only sources of surface water are a handful of springs along the slopes of the ridge and the lower parts of Malikarjun mountain. The mountain rises above the community to $2,500 \mathrm{~m}$, and its lower slopes are divided into three community forests administered by community forest user groups (CFUGs). Three additional community forests are located in other areas of the community, and the majority of households in Malikarjun are members of one of these CFUGs.

Malikarjun is located along the road that connects the district capital of Darchula with the nearest market center, Gokuleshwar, as well as Baitadi and the distant Terai beyond. During fieldwork in 2018, a short spur road connected this main artery to the Malikarjun market, but was blocked or impassable beyond. By 2020, however, 3-5 roads starting at the market or main community gate had been cleared, extended or built by the regional government further into the community. These roads are putting an increasing number of houses into direct connection with distant markets, but they have not yet significantly impacted life in the village, as very few households own vehicles that could transport their goods to larger markets. Houses are widely scattered, except for the market and community center, and are usually surrounded by or adjacent to their farming lands. All agricultural land is terraced and nearly all, with the exception of the narrow ridgetop (Figure 1), located on steep slopes. Water access is scarce throughout the community, and irrigation is non-existent except for the valley bottoms. The community are primarily subsistence farmers, with most households supplementing their income through outmigration for work in India and elsewhere in Nepal. Most of the business owners of the market shops are locals, and have their own houses and farming lands within the community.

Malikarjun is also the name of the lineage god, who was brought with the people from their original home in India several centuries ago. Malikarjun is seen as an emanation of Shiva (Sanskrit Śiva), who has chosen to dwell in a cave on Malikarjun mountain. The community settled here in response to his choice of this particular location. This temple, the mountain, and the deity who animates both, are the center of an important regional cult. The Malikarjun tradition is inextricably linked to the physical landscape, which in turn is narrated and mapped out in the origin stories contained in many of the local sacred songs. In addition to Malikarjun mountain, many members of the Malikarjun familial pantheon have their own specific sacred sites and temples up to several days travel by foot throughout the surrounding landscape. The most prominent of these within the community are two smaller temples to Latinath, the first son of Malikarjun and an emanation of Ganesh (Sanskrit Ganeśa). Sacred sites also mark the route by which Malikarjun and his people traveled from India. The female lineage is also represented in the landscape in the form of Malikarjun's seven wives, who are associated with specific temples and locations throughout the regional landscape. The principal wives, Baghashree and Shobhashree, live within the community and are connected to a series of sacred springs, whose water is used in the most importants rituals performed yearly at the Malikarjun and Latinath temples.

\section{Methods}

Fieldwork was carried out between May and June 2018, and again between March and June 2020. In 2018 this comprised a series of visits of 1 week or less, while in 2020 the research team rented a local house and lived in Malikarjun, providing an experience of the conditions of daily life in the community. The primary aim of the 2020 fieldwork was to record the sacred oral epics performed at annual festivals, which are one of the key elements in maintaining the community's ties to the land and their gods. Complications due to the Covid-19 crisis, particularly the impossibility of holding the large gatherings which are necessary for the performance of the songs, resulted in redesigning the project aims. With freed up time and resources, the team decided to focus on collecting data about the local agri-food system and its embeddedness in the spiritual landscape which is evoked in the sacred oral literature. 


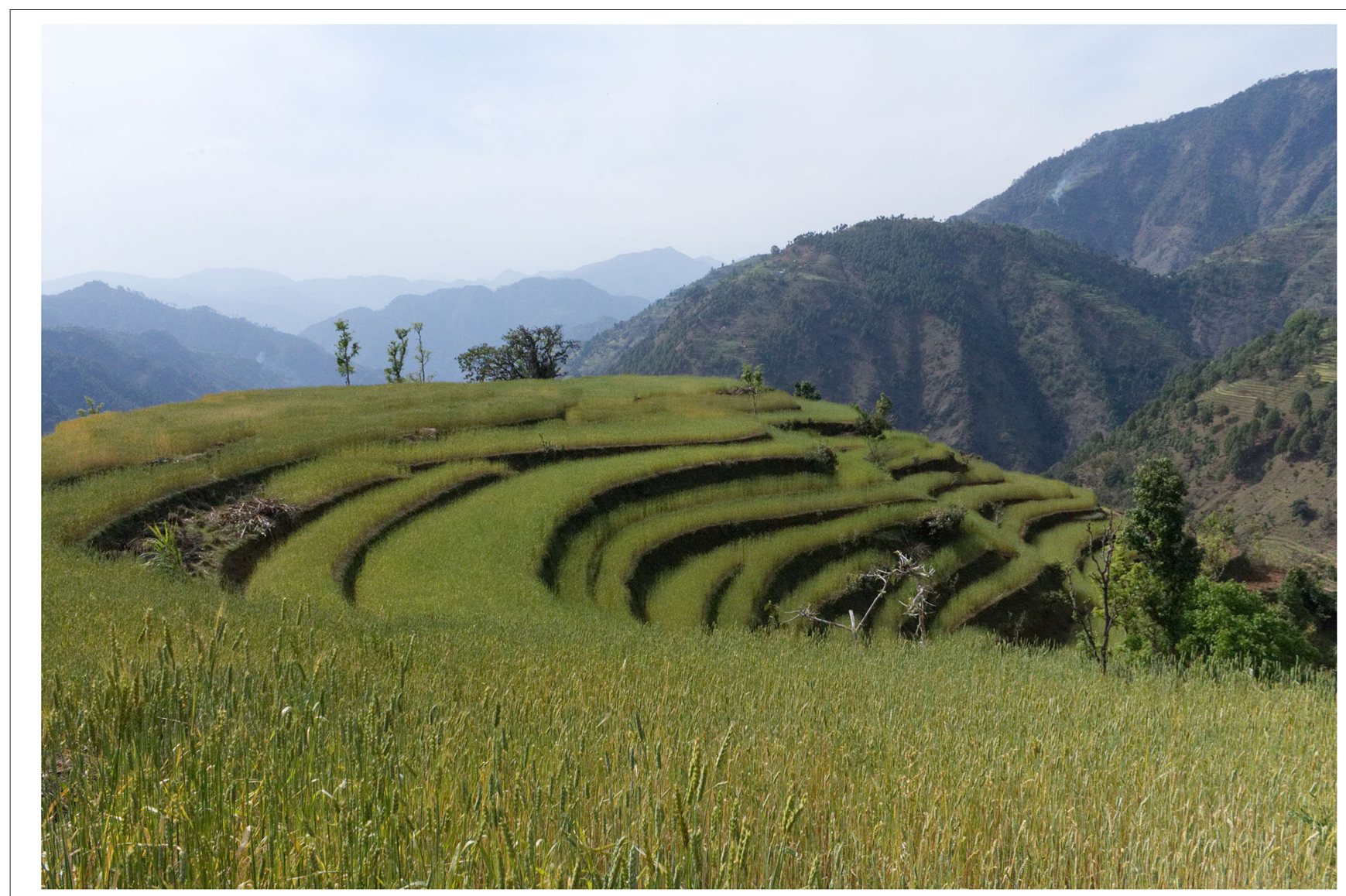

FIGURE 1 | Wheat and barley growing on terraces in Malikarjun.

Participant observation in agricultural activities and religious ceremonies; audio recording of soundscapes, stories and songs; interviews; and home garden surveys were the primary methods employed to gather data about agricultural practices, gastronomic ethnobotany, and local spiritual traditions. Author B.J. is from the region, and given his knowledge of the local Doteli dialect, acted as interpreter for interviews, translator of audio recordings, and more generally as "cultural broker" for the rest of the team. In 2018, 14 individual interviews and 15 group interviews were conducted, alongside five recording sessions of informal group singing. In 2020, 10 garden surveys, 24 individual and group interviews, and nine recording sessions of traditional songs commonly performed during festivals were conducted.

The practices and timings of the local agri-food system and rituals that will be discussed are synthesized and visually represented in a calendar (Figure 2). Calendars can be powerful tools as they allow us to visualize how agro-ecological and ritual cycles intertwine with one another. The calendar presented here encapsulates a preliminary overview of the yearly agro-spiritual cycle of Malikarjun. We took inspiration from Kassam et al. (2018), who have described ecological calendars as context-specific and "embedded in the relationships of people to their own ecosystem." Ecological calendars are inspired by historical and contemporary observation of the systems people have developed to guide their planning and decision making in a given environment. Developed over sustained occupancy of ecosystems, these commonly include forecasting methods and other methods for timing livelihood practices and their inextricable spiritual practices (Orlove et al., 2002; Mondragón, 2004; Kassam et al., 2011, 2018; Prober et al., 2011; Rautela and Karki, 2015; Cochran et al., 2016).

The home garden surveys included sketching the gardens (Figure 3), recording all species of plants, and a structured interview covering agricultural production, growing seasons and practices, grain varieties, and associated spiritual knowledge. Visual representation of the data facilitated mutual understanding with the participants. Homes were selected for these garden surveys in an attempt to represent the community's full topographical and elevational range. Further context on the results of these structured surveys was provided by the semistructured techniques used for the 24 interviews, which focused on agricultural knowledge and practices, uses of domesticated and wild plants, and associated stories and descriptions of rituals and ceremonies connected 

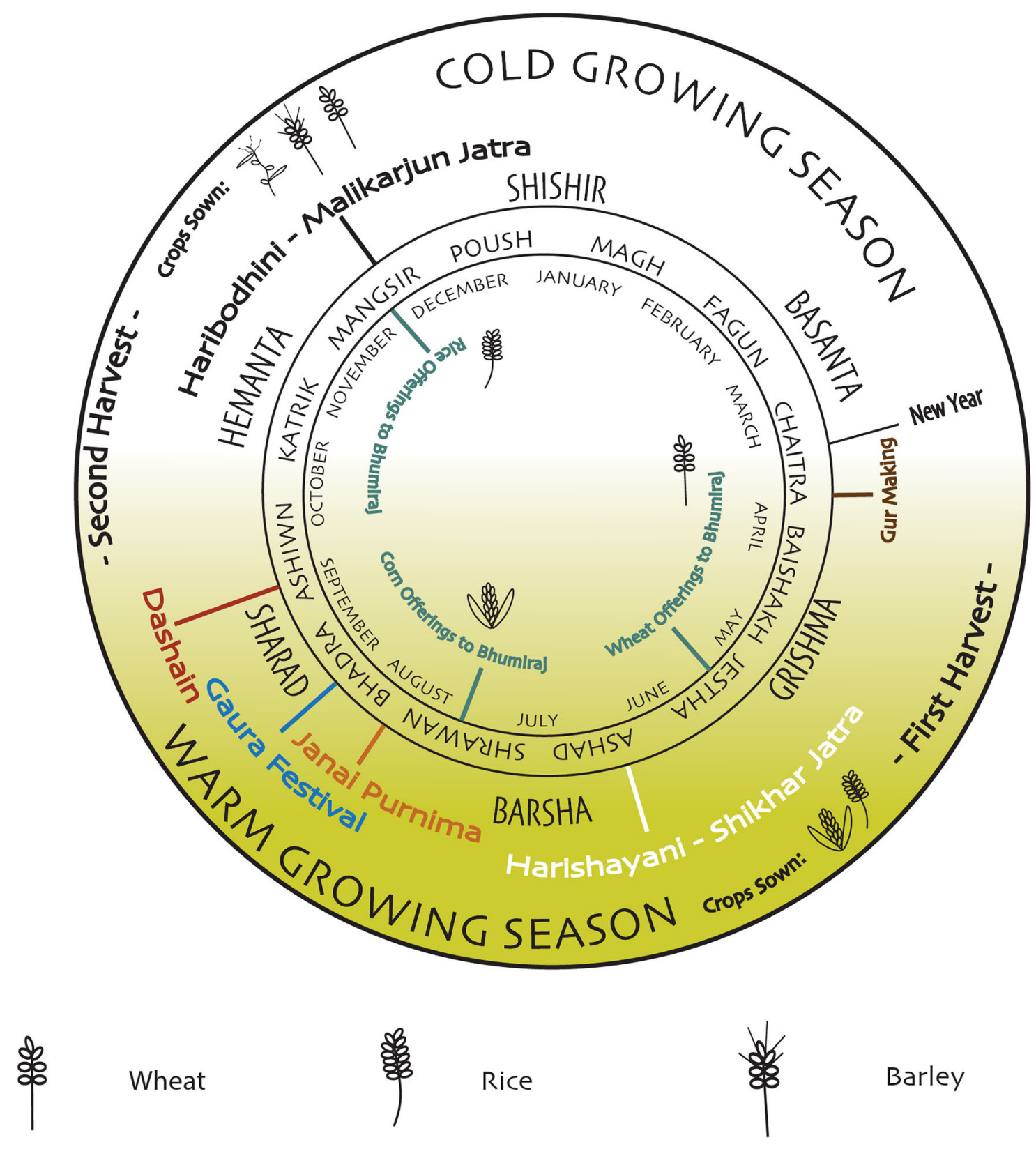

Corn

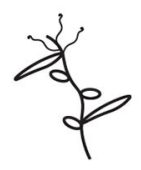

Pulses, including the culturally important Kalaun pea

FIGURE 2 | A representation of the ritual and agricultural calendar of Malikarjun, showing Nepali months and seasons alongside Gregorian months. Two agricultural seasons corresponding to the two main sowing and harvest times are visible in white and yellow, respectively. The most important crops are also indicated, namely wheat, corn, rice, barley, and pulses including the culturally important kalaun pea. The timing of the harvest offerings to the land deity Bhumiraj are indicated in the center. Key festivals are marked alongside the Hindu cosmic cycle of Haribodhini and Harishayani.

to sowing and harvesting times, or to specific plants. In 2018 the chairman of the rural municipality connected us to several initial key knowledge holders, and snowball sampling was used to expand the network. The fieldwork in 2020 built on the relationships previously created to contact additional local knowledge holders.

The Code of Ethics of the International Society of Ethnobiology guided the research, and oral prior and informed 


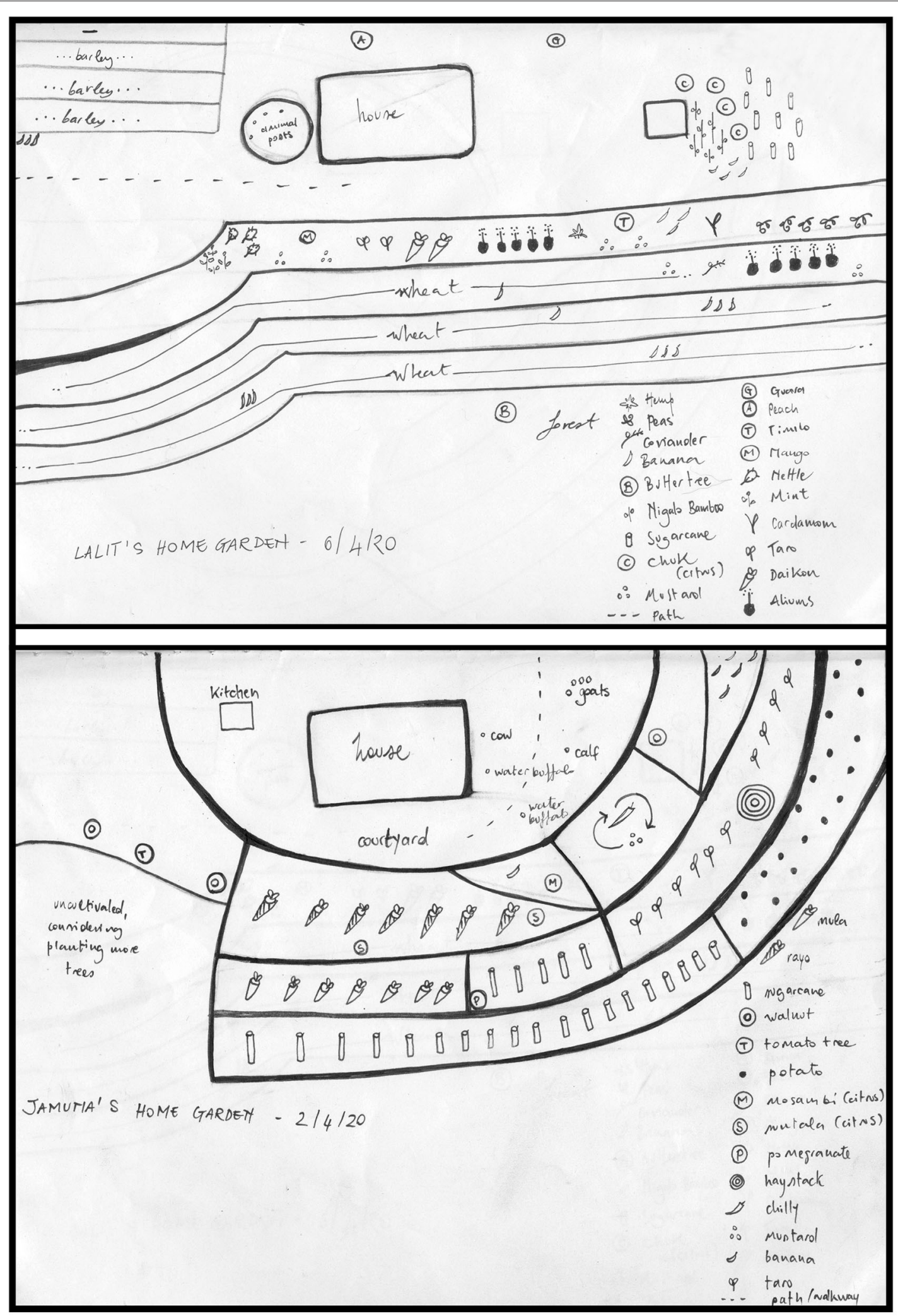

FIGURE 3 | Home garden sketches. 
consent was received for all interviews, surveys and audio/visual recordings. Most garden surveys involved a full household with husband and wife as primary respondents, whose average age ranged between 35 and 55. Children of all ages also sometimes participated in the garden surveys, as they are responsible for many important chores in the household, the garden and the fields. Grandparents would sometimes also contribute, so survey responses often benefited from intergenerational input.

Botanical specimens of ethnobotanical plants were collected in the community forests during the first phase of the research in 2018, and in 2020 some further collections of ethnobotanical, home garden and wild plants were made. Donations were made to the community forests committees where plant collection was performed to support their conservation and capacitybuilding activities. A total of 20 collecting trips were made, which yielded 156 herbarium specimens. Physical descriptions, site descriptions, GPS locations and elevation data were recorded to accompany each specimen. Permits for plant collection were issued by the national Department of Forestry in 2018 and 2020, and the local Department of Forestry office in Darchula facilitated the transportation of specimens to Kathmandu, where they are in the process of being identified and deposited at the National Herbarium \& Plant Laboratories (KATH). Plants were identified according to the Linnaean classification system in order to enable future comparative research, however local names were employed in the field because of relevance in the local community.

\section{RESULTS: FOOD SYSTEM OF MALIKARJUN}

\section{Agricultural System and Diversity}

The agricultural cycle of Malikarjun, which is typical of much of the mid-hills of Nepal (Khattri, 2012), has two growing seasons. In both home gardens and the terraced fields, crops are sown for the summer season in Baishakh or Jestha (May/June) and harvested in Ashwin or Kartik (September/October), then again for the winter season in Kartik or Mangsir (October/November) and harvested in Chaitra (March/April) (Figure 2). The main winter crop is wheat, although barley is also grown by every household (Figure 4), as much for its ritual significance as for its contribution to human and animal diets. Wheat and barley are grown separately, but both are intercropped with mustard and kalaun, a local pea variety, and more rarely with lentils, chickpeas and linseed. In the summer the main crop is corn, with households also cultivating rice whenever their land allows it (70\% of surveyed households).

Corn is intercropped with a wide variety of Cucurbitaceae vegetables and legumes, in particular soybeans, black gram, french bean, rajma bean, and black-eyed peas. Many legumes are also grown on the terraces or edges of fields rather than mixed directly in with the terrace grains. A total of 10 legume species were reported, with at least $70 \%$ of households growing kalaun pea, soybean, black gram, and black-eyed pea. Rice is intercropped with sesame, and to a lesser extent with black gram and foxtail millet, a common staple crop across far western Nepal
(Kunwar et al., 2012). More than half of the surveyed households grow a little finger millet, which is not intercropped due to its high density of growth. About one third of surveyed households also grow oats, and several grow wah, naked barley, described by locals as an old grain declining in use.

Landrace diversity varies significantly among the main staple grains. Wheat has only five reported varieties (Dauti, Bikashi, Jhuse, Chaute, Dhole), with the majority of households growing only Dauti and Bikashi. Barley is often reported to have no or only one variety, although a few households reported that it had two varieties (Jhuse and Thade). Corn has seven varieties grown in the community (Rato, Daule/Seto, Shankarmukha, Bikashi, Nanduk, Mankamana 3), including one for popcorn (Murli), although two basic red and white varieties (Rato and Seto) predominate. Rice has by far the highest diversity, with 16 reported varieties (Nanidhan, Choti, Khele, Basmati, Rate, Bure, Rebele, Naka, Jini, Ara, Kaldhan, Kaljade, Jaule, Bungau, Chamade, Tede), although most households reported growing 3-7 varieties. Many of these appear to be local, perhaps unique to the region. Oats and millet were also reported to have no or only one variety. Peas were recognized as being either typical peas, or kalaun, a local variety with particular culinary and spiritual significance to the community (Figure 5).

It appears that landrace diversity is due to several different factors. Rice varieties are usually described as having particular qualities and are used for specific purposes, such as the highlyspecialized Kaldahn, a rare variety which is harvested before the grains fully mature, so that it can be crushed, mixed with milk and sugar and eaten fresh. In the case of rice, it appears that the culinary qualities and associated cultural values of different varieties have led to their preservation, which is why they are stored and consumed separately. Heirloom varieties like the kalaun pea have their own origin stories, and their use is prescribed in important rituals like the women's festival of Gaura. These biocultural indicators explain both landrace diversity and preference for local cultivars. Wheat varieties, on the other hand, are preserved because of their variability in growing season, yield, response to drought, etc. Aside from those kept for seed, different wheat varieties are mixed together for consumption. In this case, it appears that landrace diversity is being preserved in order to increase the resilience of winter crops against fluctuations in climate and precipitation.

Home gardens contribute to food and household income, producing a variety of vegetables, fruits, and other essential products (Table 1). In fact, drawing a division between "home gardens" and "agricultural fields" is impossible; in lived experience, the location of a particular plant is a question of proximity to the home. The gardens and terraced fields blend seamlessly together, a porous boundary that oscillates throughout the seasons and years. Gautam et al. (2008) have described home gardens as "a land use practice around a homestead where many annual and perennial plant species are planted and maintained by the members of the household." Home gardens in Nepal have also been described as "a micro-environment composed of a multispecies ..., multistoried and multipurpose garden situated close to the homestead (Gautam et al., 2006)" For the purpose of this study we have defined the home garden as the portion of ground 


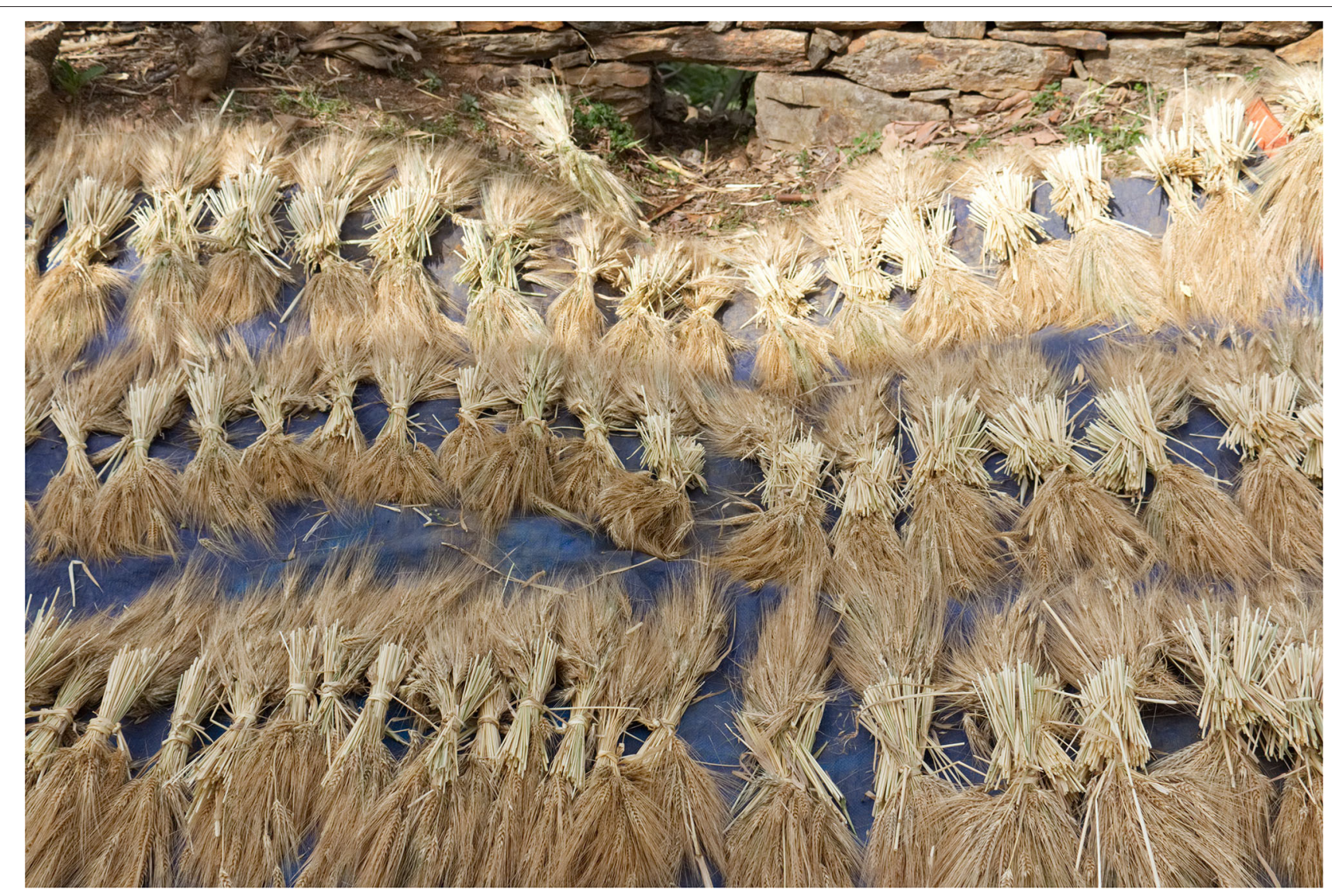

FIGURE 4 | Barley harvest sorted and left to dry

devoted to vegetables, trees, legumes, or agricultural plants other than the staple grains described above.

Home gardens are relatively small and generally aimed at fulfilling household needs rather than producing goods for sale, although many households do sell surplus produce or valuable commercial plants like okhars (Juglans regia) and timur (Zanthoxylum armatum) from the home garden (Kunwar et al., 2012). A few households have been given the materials to build greenhouses by the USAID project PAHAL, local nonprofit Community Rural Development Society (CRDS-Nepal), or other organizations, which allows them to grow tomatoes or other crops for sale. Many households also sell fruit, which is generally produced in excess of family needs. One of the surveyed households has transitioned away from growing grains to focusing exclusively on trees, and has a current orchard of more than 2,000 fruit and nut trees of 27 species.

In complete surveys of 10 home gardens, 91 species of fruits, vegetables and other plants were cultivated (see Table 1). Individual households grow 32-59 species of plants, including grains and legumes. The 38 species of vegetables includes a high diversity of Cucurbitaceae (11 spp). More than $80 \%$ of surveyed households grow onion, garlic, potato, tomato, daikon radish, mustard greens, cress, ridge gourd, and cucumber. Taro, pumpkin, chili and fenugreek are also commonly cultivated, and a wide variety of other vegetables and spices, depending on taste, enthusiasm, and garden characteristics. The 23 species of fruit trees include a high diversity of citrus (6 spp), and more than $80 \%$ of households grow peach, banana and citron. At least $50 \%$ of households also grow tangerine, orange and a local variety of sour pomegranate called darim.

Not all cultivated home garden plants fall into the "food" category; some are also grown for seed, nuts, oil, medicine, fiber, or flowers that can be used as offerings in household rituals (pujas). We found 18 additional non-tree species, which includes some semi-wild plants at the interface between cultivated and uncultivated, such as mint, cannabis, buckwheat (Fagopyrum spp), Chenopodium, and Amaranthus, as well as planted flowers useful for puja (chrysanthemum, hibiscus, Datura, crape myrtle, and rose). There were also nine additional tree species, although only walnut was grown by more than $80 \%$ of households. The remaining trees include those useful for fodder, a spiritually significant bamboo also used for making a wide variety of baskets, a Bauhinia with edible buds, and a number of other useful species with commercial value (butternut, soap nut, cinnamon, and Zanthoxylum armatum) (Kunwar and Bussmann, 2009).

The entire agricultural system of Malikarjun, and thus the lives of community members, is intimately linked to their practice of animal husbandry. Every household keeps animals, in numbers roughly equal to but usually slightly exceeding the number of human household members. Domestic animals are cow, water 


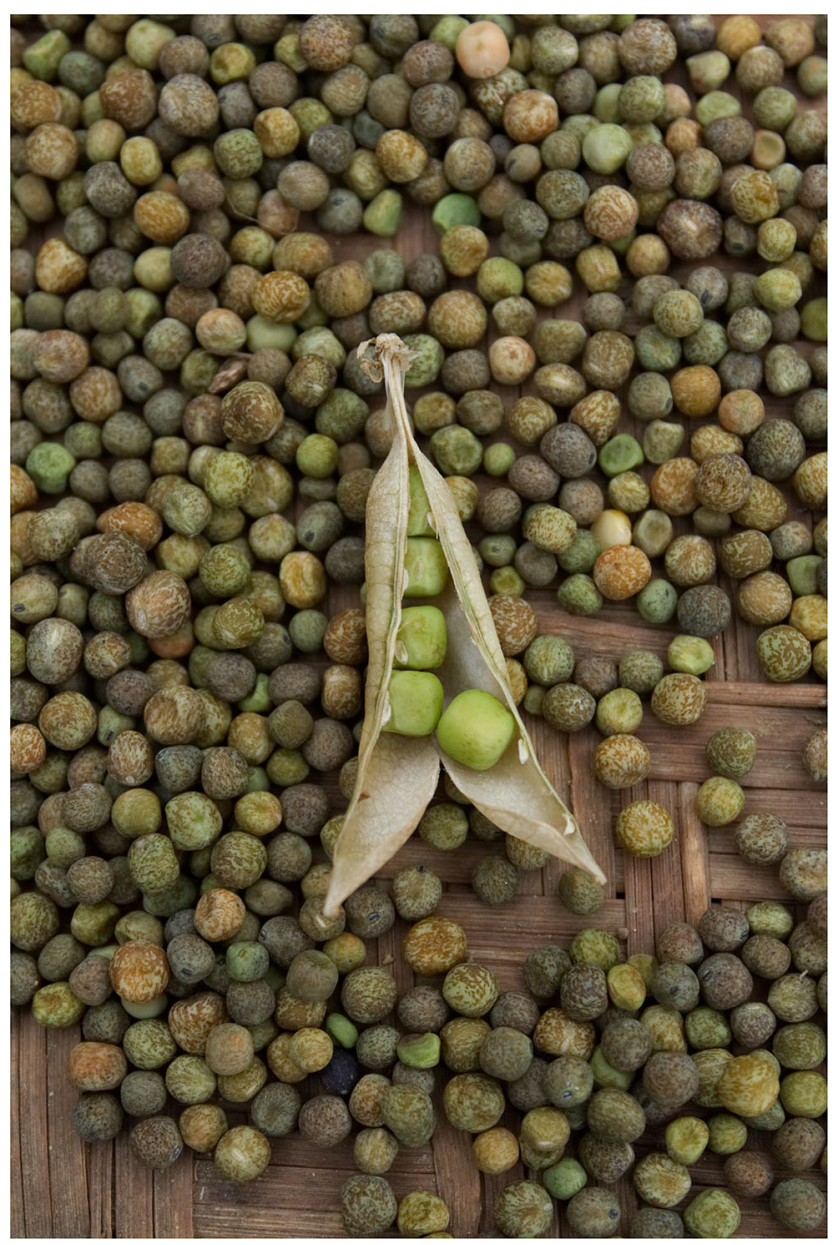

FIGURE 5 | Kalaun, a local pea variety with ritual significance in the community.

buffalo and goat; there are no sheep or yak at this elevation, and $<5$ horses in the community. The animals are kept at night in the ground story of the home, with the second floor housing the human inhabitants. Bedding plants are added daily to the rooms where animals are kept. The urine and dung mixes with successive layers of bedding and slowly breaks down. Twice a year, during the preparations of the fields for the planting of summer and winter crops, this mixture is shoveled out of the animals' quarters and left for a few days to decompose into fertilizer, which is carried out to the fields and spread on each terrace. This fertilizer, produced on a household scale, is the only input used in Malikarjun, and thus the role that these animals play in the agricultural system is critical.

\section{Agricultural Labor}

Agricultural labor is differentially distributed throughout the seasons and between groups in the community. Farming is generally a female domain, and women are the main tenders of the fields during the long periods waiting for the growth and ripening of crops. During the intensive periods of planting and harvest, all available community members are mobilized, with extended families and neighbors often gathering together into small groups to more efficiently harvest one household's crops at a time. Plowing and tilling is done by men, using bulls and handmade wooden plows, and women and children follow them seeding the rows during planting. Children will often assist with the harvest and planting, but do not work much in the fields at other times.

The home garden is tended by a collaborative and flexible group of adults. Women are often responsible for planting many of the vegetables and culinary plants, while men may plant fruit trees, and an elder man might zealously tend a little patch of tobacco. Animal husbandry, however, is largely a female responsibility. Women spend much of their time gathering fodder (two or three times a day) and bedding (daily or a few times a week), often at great distances from the house, and carrying it back to the animals in the ubiquitous dhoko, bamboo carrying baskets. Women also milk the buffalo and cows, and manage most of the process of dairy production, including making buttermilk, ghee, and sometimes a kind of fresh cheese called galyun. Children and women are often the ones looking after animals when they are sent to graze in the community forests. Children and teenagers, particularly boys, are sent with the animals to more distant grazing grounds which some families have inherited rights to use. Men and the elderly will look after the home garden or graze the animals depending on age, ability, fitness and interest.

The tradition of making gur, an unrefined solid sugar produced from sugarcane juice, encapsulates the communal tradition of shared intergenerational and multispecies agricultural labor. Each household grows a variable amount of sugarcane during the winter season. Once the sugarcane is ready to be harvested, the entire process becomes communal; all genders and generations partake. Groups of multiple households of relatives and neighbors gather together, with women moving from house to house and cutting the cane, while the men assemble a sugarcane press, which is communally owned, on a flat spot kept for this purpose near the participating households. Over a few days or up to a week, the sugarcane yields of all the families are processed, and the final product is distributed between the participating households. Animals initiate the heavy labor of pushing the beam that runs the sugarcane press. However, by late morning it is too hot for the animals to continue, and children and women take over the working of the press, laughing and joking as they work. Small children or elderly women usually feed sugarcane into the press, a task they can attend to while sitting comfortably on the ground, with an eye to the turning beam passing above their heads (Figure 6). Men are responsible for building the fires and overseeing the boiling and slow reduction of the juice, in huge cauldrons over many hours. When the gur is nearly ready, elder men direct the pouring of the thick sugarcane syrup into a hollowed out tree trunk, and the stirring and forming into balls as the gur cools and solidifies.

\section{Consumption Patterns and Important Foods}

The household diet is vegetarian and based primarily on a combination of rice and other grains with pulses, vegetables and dairy products. Morning meals usually consist of semolina halva 
TABLE 1 | Home garden survey results of crops grown in gardens and terraced land include English names, percentage of households cultivating the plant, a name in the local Doteli dialect, a Nepali name, and the Linnean family and name.

\begin{tabular}{|c|c|c|c|c|c|}
\hline English name & $\%$ Cultivating & Local name & Nepali name & Family & Latin name \\
\hline \multicolumn{6}{|l|}{ Grain (8 spp) } \\
\hline Corn & 100 & Ghoga & Makai & Poaceae & Zea mays $\mathrm{L}$. \\
\hline Wheat & 90 & Gahun & Gahun & Poaceae & Triticum aestivum L. \\
\hline Barley & 90 & Jaun & Jaun & Poaceae & Hordeum vulgare $\mathrm{L}$. \\
\hline Rice & 70 & Dhan & Dhan & Poaceae & Oryza sativa L. \\
\hline Finger Millet & 60 & Kodo & Kodo & Poaceae & Eleusine coracana (L.) Gaertn. \\
\hline Oats & 30 & Jwato & Jai & Poaceae & Avena sativa L. \\
\hline Naked Barley & 20 & Wah & Uwa & Poaceae & Hordeum distichon L. \\
\hline Foxtail Millet & 10 & Kaun & Kaguno & Poaceae & Setaria italica (L.) P.Beauv. \\
\hline \multicolumn{6}{|l|}{ Legumes (10 spp) } \\
\hline Kalau Pea & 80 & Kalaun & Kerau & Fabaceae & Pisum sativum L. \\
\hline Black-eyed Peas & 80 & Shotta & Gajalu bodi & Fabaceae & Vigna unguiculata (L.) Walp. \\
\hline Black Gram & 80 & Mas & Mas & Fabaceae & Vigna mungo (L.) Hepper \\
\hline Soybean & 70 & Bhatt & Bhatmas & Fabaceae & Glycine max (L.) Merr. \\
\hline Lentils & 40 & Masoor & Masoor & Fabaceae & Lens culinaris Medik. \\
\hline Kidney Bean & 30 & Rajma & Ghiu simi/Rajma & Fabaceae & Phaseolus vulgaris L. \\
\hline Rice Bean & 30 & Gurans & Jhilangi & Fabaceae & $\begin{array}{l}\text { Vigna umbellata (Thunb.) Ohwi and } \\
\text { H.Ohashi }\end{array}$ \\
\hline Horse Gram & 20 & Gaut & Gahat & Fabaceae & Macrotyloma uniflorum (Lam.) Verdc. \\
\hline Peas & 10 & Matar/kalaun & Kerau & Fabaceae & Pisum sativum L. \\
\hline Green Gram & 10 & Mung & Mung & Fabaceae & Vigna radiata (L.) R.Wilczek \\
\hline \multicolumn{6}{|c|}{ Vegetables (38 spp) } \\
\hline Coriander & 100 & Dhaniya & Dhaniya & Apiaceae & Coriandrum sativum L. \\
\hline Mustard & 100 & Toori & Toori & Brassicaceae & Brassica juncea (L.) Czern. \\
\hline Onion & 90 & Piaj & Pyaj & Amaryllidaceae & Allium cepa L. \\
\hline Potato & 90 & Aloo & Aloo & Solanaceae & Solanum etuberosum Lindl. \\
\hline Sugarcane & 90 & Likhu & Ukhu & Poaceae & Saccharum officinarum L. \\
\hline Garlic & 80 & Lasun & Lasun & Amaryllidaceae & Allium sativum $\mathrm{L}$. \\
\hline Tomato & 80 & Tamatar & Golbheda & Solanaceae & Solanum lycopersicum L. \\
\hline Daikon & 80 & Mula/choto & Mula & Brassicaceae & $\begin{array}{l}\text { Raphanus raphanistrum subsp. sativus (L.) } \\
\text { Domin }\end{array}$ \\
\hline Broadleaf Mustard & 80 & Rayo & Rayo & Brassicaceae & Brassica juncea (L.) Czern. \\
\hline Cress & 80 & Chansoor & Chamsoor & Brassicaceae & Lepidium sativum L. \\
\hline Ridge Gourd & 80 & Toriya & Pate ghiraula & Cucurbitaceae & Luffa acutangula (L.) Roxb. \\
\hline Cucumber & 80 & Kakara & Kakra & Cucurbitaceae & Cucumis sativus L. \\
\hline Pumpkin & 70 & Farsi/Kadu & Farsi & Cucurbitaceae & Cucurbita L. hybrids \\
\hline Spinach & 70 & Palungo & Palungo & Amaranthaceae & Spinacia oleracea L. \\
\hline Taro & 70 & Pidau & Pidalu & Araceae & Colocasia esculenta (L.) Schott \\
\hline Chili & 60 & Khursani & Khorsani & Solanaceae & Capsicum annuum L. \\
\hline Fenugreek & 60 & Nethi & Methi & Fabaceae & Trigonella foenum-graecum L. \\
\hline Bitter gourd & 50 & Tite karela & Tite karela & Cucurbitaceae & Momordica charantia L. \\
\hline Bottle gourd/Opo & 50 & Lauka & Lauka & Cucurbitaceae & Lagenaria siceraria (Molina) Standl. \\
\hline Ash gourd & 50 & Kopindo & Kupindo & Cucurbitaceae & Benincasa hispida (Thunb.) Cogn. \\
\hline Yam & 50 & Gittha & Tarul & Dioscoreaceae & Dioscorea deltoidea Wall. Ex Griseb. \\
\hline Chives & 40 & Sekuwa & Jimbu & Amaryllidaceae & Allium schoenoprasum L. \\
\hline Eggplant & 40 & Baigan & Bhanta & Solanaceae & Solanum melongena Wall. \\
\hline Cabbage & 40 & Kopi & Banda & Brassicaceae & Brassica oleracea L. \\
\hline Cauliflower & 40 & Cauli & Cauli & Brassicaceae & Brassica cretica Lam. \\
\hline Sesame & 40 & Til & Til & Pedaliaceae & Sesamum indicum L. \\
\hline Bell Pepper & 30 & Simla/sage Khursani & Bhede Khorsani & Solanaceae & Capsicum annuum L. \\
\hline Carrots & 30 & Ganjer & Ganjar & Apiaceae & $\begin{array}{l}\text { Daucus carota subsp. sativus (Hoffm.) } \\
\text { Arcang. }\end{array}$ \\
\hline
\end{tabular}


TABLE 1 | Continued

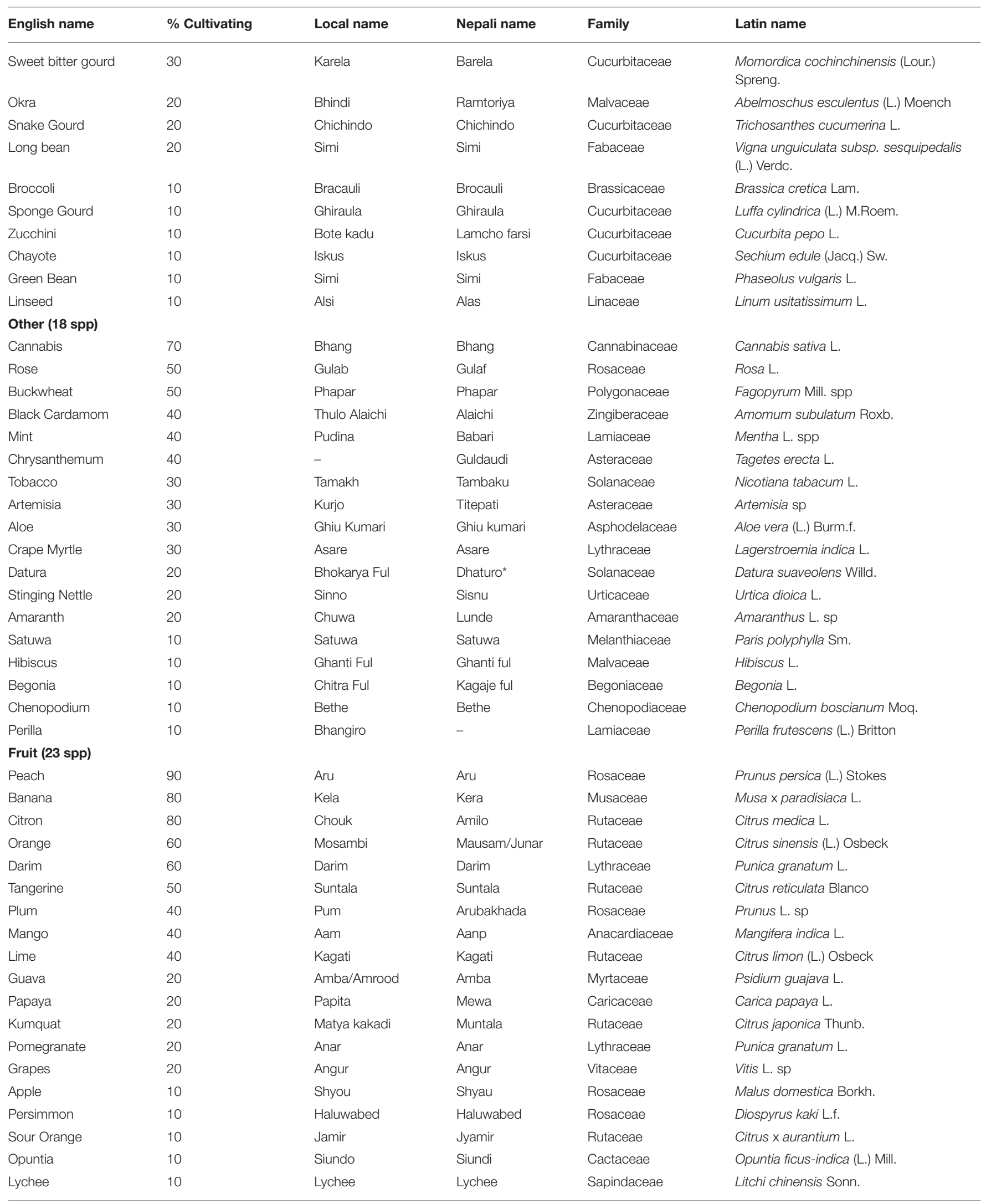


TABLE 1 | Continued

\begin{tabular}{|c|c|c|c|c|c|}
\hline English name & $\%$ Cultivating & Local name & Nepali name & Family & Latin name \\
\hline Lapsi & 10 & Lapsi & Lapsi & Anacardiaceae & $\begin{array}{l}\text { Choerospondias axillaris (Roxb.) B.L.Burtt } \\
\text { and A.W. Hill }\end{array}$ \\
\hline Kaphal & 10 & Kaphal & Kaphal & Myricaceae & Myrica esculenta Buch.-Ham. ex D. Don \\
\hline Amla & 10 & Amla & Amala & Phyllanthaceae & Phyllanthus emblica L. \\
\hline Tree Tomato & 10 & Rukh tamatar & Tyammatar & Solanaceae & Solanum betaceum Cav. \\
\hline \multicolumn{6}{|c|}{ Other Trees (12 spp) } \\
\hline Walnut & 90 & Okhad & Okhar & Juglandaceae & Juglans regia L. \\
\hline Timilo & 70 & Timilo & Timilo & Ficaceae & Ficus auriculata Lour. \\
\hline Bamboo & 50 & Ninglo & Nigalo & Poaceae & Drepanostachyum falcatum (Nees) Keng f. \\
\hline Timur & 40 & Timur & Timur & Rutaceae & Zanthoxylum armatum DC. \\
\hline Dudilo & 40 & Dudilo & Dudhilo & Ficaceae & Ficus neriifolia Sm. \\
\hline Belta & 30 & Belta & Berulo & Ficaceae & Ficus subincisa Buch.-Ham. ex Sm. \\
\hline Butternut & 20 & Chiuri & Chiuri & Sapotaceae & Diploknema butyracea (Roxb.) H.J.Lam \\
\hline Cottontree & 20 & Kapash & Kapash & Malvaceae & Gossypium arboreum L. \\
\hline Oak & 20 & Bnaj & Katus & Fagaceae & Quercus oblongata D.Don \\
\hline Koiralo & 20 & Koiral & Koiralo & Fabaceae & Bauhinia variegata $\mathrm{L}$. \\
\hline Rittha & 10 & Ritha & Rittha & Sapindaceae & Sapindus mukorossi Gaertn. \\
\hline Cinnamon & 10 & Dalchin & Tejpat & Lauraceae & $\begin{array}{l}\text { Cinnamomum tamala (Buch.-Ham.)T.Nees } \\
\text { and Eberm. }\end{array}$ \\
\hline
\end{tabular}

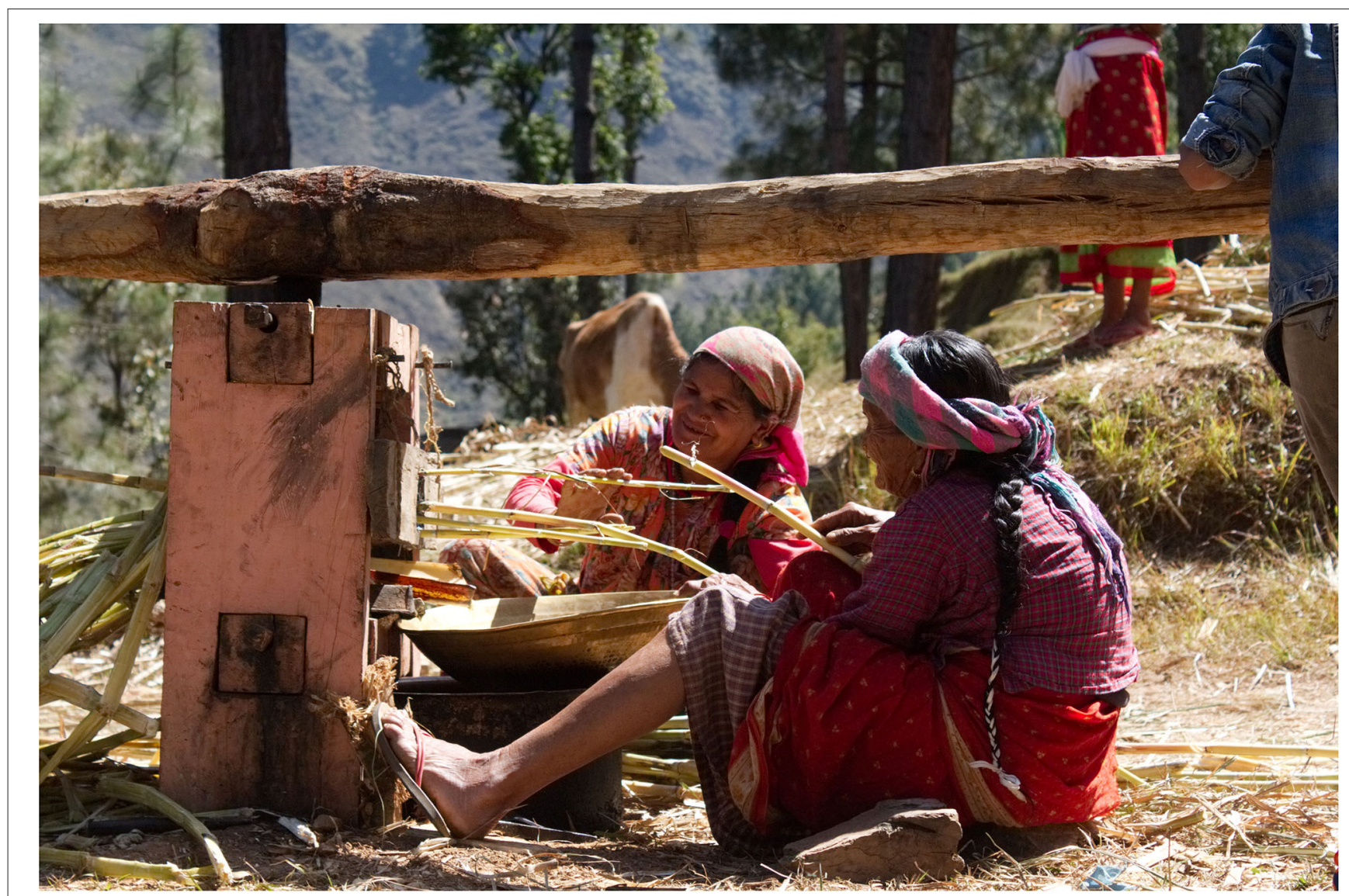

FIGURE 6 | Women feeding sugarcane into a gur press. 
or roti made of corn or rice flour accompanied by a vegetable dish. The midday and evening meals are derived from the classic Nepali dahl bhat meal of rice or roti, a dahl of cooked pulses, a vegetable tarkari dish, and a dish of cooked greens, saag. However, in homes, not all of these elements will usually be present in any given meal. Achar, a condiment which is either a fermented pickle or freshly made sauce (mint, sesame, tomato, hempseed, etc.), accompanies most meals. In far western Nepal, rice is usually not consumed after dark, so for the evening meal roti of wheat or corn flour usually accompany pulses and/or vegetable dishes.

Cows and water buffalo produce sufficient milk for household dairy needs. Buttermilk is usually prepared once daily in the early morning, and the butter produced as a side product is saved and clarified into ghee. Milk and buttermilk are drunk and used for cooking. Buttermilk is an important element of local cuisine and is often added to vegetables dishes or other regional dishes such as dukpa, a buttermilk sauce with dumplings made from the kalaun pea. Vegetable dishes and dahls are cooked with either ghee, depending on how much a household is able to produce, or vegetable oil purchased from outside the community. Other kinds of cooking oils are also sometimes produced and used locally, including from mustard seed, linseed, and butter nut (Diploknema butyracea). Dishes are seasoned with masalas made from a wide variety of spices, many of which are produced in the home gardens, such as garlic, turmeric, coriander, cumin, black cardamom, mustard, etc.

Enough wheat, corn, barley, and vegetables are produced by most families to meet household needs. Whether a household can rely solely on its crops of grains, pulses and vegetables may depend on the amount of land cultivated by the family and the available workforce. The largest component of the diet purchased from outside the home is rice, which can only be produced on a limited amount of land in the community. Many households may also need to purchase dahl to supplement their production, and there is a ready household trade in spices, seeds and grain.

Wild plants do not contribute significantly to the diet, although there are many species which are known and used. Perhaps the most popular is kaaphal (Myrica esculenta), a common tree in local oak forests, whose fruit is widely gathered and enjoyed in the spring, and sometimes sold to visitors and buses passing along the road to Gokuleshwor. A number of other wild fruits, notably ainselu (Rubus ellipticus) and kirimuda (Berberis asiatica), are also eaten by children and adults in the fields and forest edges. A few other wild species are sought out and brought back to the home, including the fern liudo (Dryopteris cochleata), the young greens of jarko (Phytolacca acinosa), and the buds of koiralo (Bauhinia variegata). Wild yams, tarul (Dioscorea deltoidea), are often dug and consumed in the forest, either raw or roasted. The leaves of buckwheat or phapar (Fagopyrum esculentum and F. tataricum), which grow on the edges of terraces and gardens, are commonly gathered and cooked as saag.

Meat is generally considered an impure food in Hinduism, so its consumption is fairly limited and it is often excluded from the household kitchen. Nonetheless many people do occasionally eat goat, which is not milked like cows and water buffalo. Goats are bought and sold and can be another significant source of household income. Goats are also sacrificed and offered to a variety of gods and local deities, often at prescribed locations and during specific festivals and life events (Gray, 1979; Govindrajan, 2015). A variety of special foods and dishes are prepared at temples and during festivals which are not part of typical household cuisine, such as mohan bhag (food of god), toasted wheat flour with ghee, coconuts and other condiments. The main meal eaten at festivals consists of poori, rice, tarkari, dahl, etc., while fruits and sweets are offered as prasad, or blessings.

\section{Agro-Spiritual Cycle}

The agricultural cycle of Malikarjun is embedded within the traditional Hindu Bikram Sambat calendar, which lays out the timing of festivals and prescribes auspicious and inauspicious dates and periods for nearly every kind of life activity. This 12month lunisolar calendar (Figure 2) begins with the month of Baishakh (roughly corresponding to mid-April to mid-May), and is divided into six ritu, or seasons. The spring season of Basanta is characterized by warm temperatures. In the summer season of Grishma, rice is sown, which grows throughout the monsoon season of Barsha. It is followed by Sharad, the festival season, when rice is harvested, and then the winter seasons of Hemanta and Sisir. Each major event in the agricultural cycle is reflected in this calendar, and at the same time, lived experience in the fields contributes to shaping the calendar's local manifestation by determining the precise timing of certain festivals and events.

The two most important festivals in Malikarjun are local versions of Haribodhini and Harishayani, which are celebrated throughout the Hindu world. Hari refers to the god Vishnu (Sanskrit Visnu), the preserver of the universe, who is understood to undergo an annual cycle that is linked with the seasonal cycle of the earth. During Harishayani ("Hari sleeps"), in Shrawan (June/July), Vishnu goes to sleep in the cosmic realm and manifests on earth, bringing with him the fertility that manifests in the monsoon rains and the growth of the summer rice and corn. Then in Poush (November/December), on Haribodhini ("Hari wakes"), Vishnu leaves the earth and wakes up once again in the cosmic realm, releasing the earth to undergo winter. The months of Poush and Magh (roughly December to February), during Hari's absence, are believed to be the least fertile time of the year, and thus not a propitious time for marriage.

In Malikarjun these two festivals are known as Shikhar Jatra (Harishayani) and Malikarjun Jatra (Haribodhini), and both are celebrated by festivals that draw thousands of people to the community to undertake jatra, pilgrimages to the Shikhar (ridge) of the sacred mountain (Figure 7), the dwelling place of Malikarjun the deity. Shikhar Jatra is intimately linked with the harvest of the winter crops, in particular barley, which is recognized as the most pure of all the crops grown in Malikarjun. In an outbuilding of the main temple complex, ripe heads of recently-harvested barley are placed on the earthen floor, and milk (another pure substance) is poured over them each day until they sprout. On the 8th day from their sprouting, some of the seedlings are uprooted and offered to Malikarjun at the main temple. On the following day, more seedlings are uprooted and offered to Balichan, a companion deity of Malikarjun. Then 
on the 10th day from sprouting, all the remaining seedlings are uprooted and brought to the top of the sacred mountain to offer to Malikarjun (and by extension, Shiva and all the other gods).

The other staple grains, although they are not seen as intrinsically pure like barley, have their own special times of offering. In the month of Jestha, just after the spring harvest, heads of new wheat are ground into flour, which is made into rotis and offered to Bhumiraj, the "lord of the earth," who is responsible for caring for the soil. Then in Shrawan or Bhadra, during the Janai Purnima festival when Hindu men renew their janai, or sacred thread, whole heads of recently harvested corn are offered. Finally in Mangsir, the recently harvested rice is offered. Each family makes their offerings of grain to Bhumiraj at a site they have selected in their terraced fields, often marked with a white dhaja or prayer flag, as well as to Malikarjun at one of the main temples. After offering grain to these main deities, people are free to offer at other locations and to any other gods that they may have a local or familial connection to. Not only grains, but all the most important "fruits" of agricultural production are first offered to the gods before being consumed and used by people, including newborn calves, a cow's first milk, freshly-made gur, etc.

The offering of grains and other agricultural products to the gods, in recognition of their critical role in plant growth and health, is not the only way in which the agricultural system of Malikarjun is connected to spiritual practice. Nearly every offering, blessing, or ritual employs agricultural products, in particular pure substances like milk and barley, as well as rice, fruits such as banana, which represent fertility, and various flowers which are grown in the household gardens specifically for this purpose. For example, in mid-Chaitra (April), in the midst of the spring harvest, people bless the temples, their houses, storehouses, and even the large chests used for storing grain by applying tika to them made of cow dung (another pure substance), with sprigs of newly-harvested barley, kalaun pea and mustard stuck into the dung (three plants which are intercropped during the winter growing season). Tika, marks made on the forehead with colored pastes, rice and other substances (similar to bindi), are applied when people visit temples, perform rituals, welcome guests, practice puja, or during any other spiritual practice in Nepal and throughout the Hindu world. As such, the placing of tika on buildings and temples associates these structures with the human body and identifies them as carriers of divine energy.

Another clear example of the interweaving of spiritual and agricultural practice is the annual women's festival of Gaura, a local expression of a wider Hindu festival unique to the far western region of Nepal. This festival celebrates Gauri (Sanskrit Gaurī), a form of devi or the goddess, who embodies motherhood, nourishment and fertility. Gauri is strongly associated with a feminine nurturing principle, and this is reflected in the nature of the Gaura festival, which culminates in women dancing in a circle, singing and giving blessings so that their families, community and land may continue to thrive, nourish and be nourished "as long as there is snow in the Himalayas, as long as there is water in the seas." Gaura lasts for 4 days of rituals and culminates in a final community-wide festival. On the 1st day, women bring a special mix of grains and pulses called biruda (wheat, kalaun pea, horse gram, black gram, and rice bean) to one of the sacred springs associated with Malikarjun's wives (Figure 8), and soak it in the water from the spring. Every household contributes their own biruda, which is grown especially for use in Gaura. On the 2nd day, the women wash the biruda five times in the water from the spring. On the 3rd day, they build and decorate a statue from a wide range of natural and pure substances, including flour made from the biruda, flowers, fruits, copper, etc. New duvdhagas, the female sacred thread, which is unique to far western Nepal, are hung on the statue to offer and bless them. On the 4th day, the women exchange their old duvdhagas for the new ones, taking them from the statue. The statue is then brought to Malikarjun Mandir, where multiple smaller "sister Gauras" meet and offer their statues and biruda at the temple. The women then bless their husbands and each member of their family in turn, after which the biruda is distributed among all households in the community. The typical blessing used at Gaura and other holidays employs many images of flourishing to describe different manifestations of fertility:

A hundred festivals, a hundred celebrations

May you celebrate; biruda of Panchami

Jamara of Dashain, beaten rice of Dutya

May you have rice and milk

May you have a comfortable bed to sleep on

May you have a pair of bulls for ploughing

May you have water from the spring to drink

May you marry the daughter of a noble

May you receive the blessings of God

May you hold the favor of the king

May you spread like a lawn of $d u b o$ grass

May you spread like the banana

May you bend like the uvula

May you blossom as fluff

As long as there is snow in the Himalayas

As long as there is water in the seas

May you live forever!

The three festivals specifically mentioned evoke the festival season of Sharad by identifying the biruda mix of Gaura; the barley from which jamara (germinated seeds given by the elders as a blessing with tika) is made during the important Dashain festival, and the rice which is beaten and offered during other festivals. All of these crops are either sowed or harvested during the Sharad festival period, so that the rituals indicated in the Gaura blessing encompass the entire annual agro-spiritual cycle.

Agricultural rituals are not only connected to the major grains and pulses grown in the community. In the household gardens, each woman maintains a tulsi (Ocimum tenuiflorum) or holy basil shrine (Figure 9), which is commonly built facing the east. Tulsi is a holy plant in Hinduism with a complex origin story which culminates in a mythic woman committing suicide after Vishnu deceives her into believing that he is her husband (Narayan, 1997). In compensation, she is turned into the tulsi plant. Each year on Haribodhini, the tulsi plant is ritually married to Vishnu in the form of sugarcane. Tulsi also plays an important role during human wedding ceremonies and in the annual 


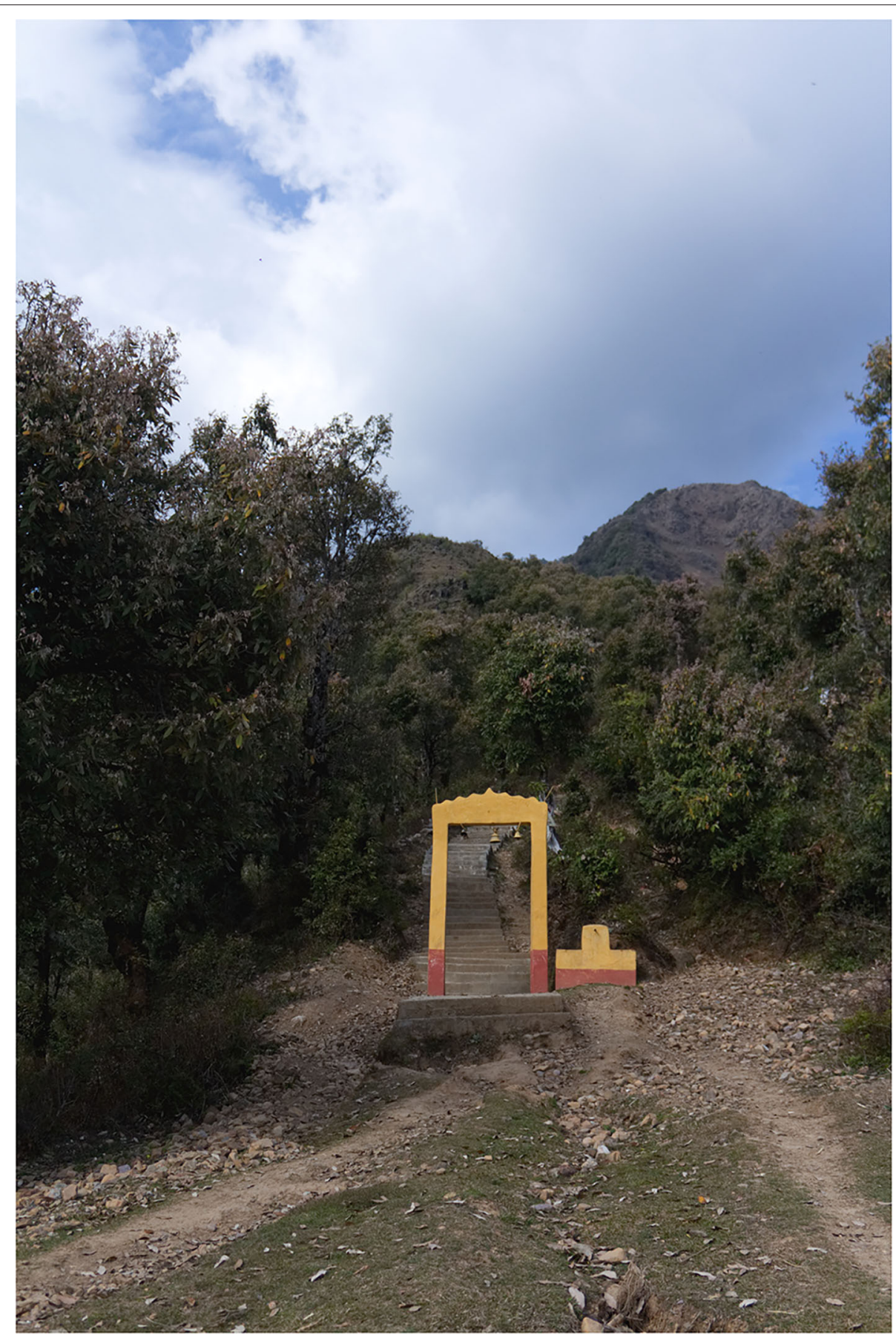

FIGURE 7 | One of the last gates before the Shikhar (ridge) of Malikarjun mountain visible beyond.

ancestral rites, in which tulsi leaves are used to purify the offering water, and the soil from which it grows is used in the offering shrine. Women make daily offerings at the tulsi shrines from the moment the seeds are sown on Harishayani. The offerings include incense and diyo, or oil offering lamps with cotton wicks made from either commercially available cotton or the cotton tree, kapash (Gossypium arboreum), which is sometimes grown in household gardens. Tulsi shrines can be understood as the domestic and private expression of the public female ceremonial role in ensuring fertility and prosperity for family, community, and land, which is embodied in the rituals and blessings of Gaura. 


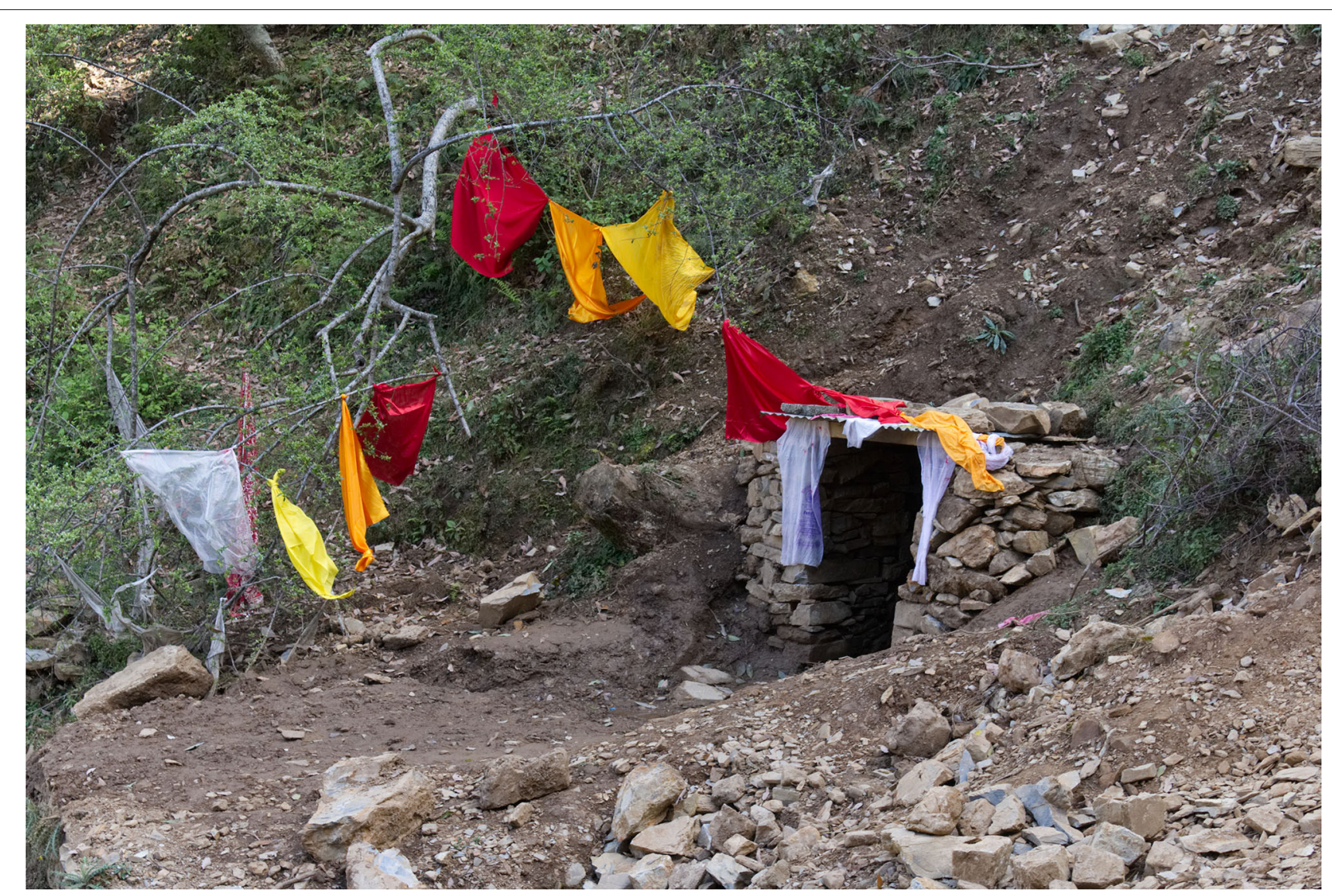

FIGURE 8 | The Malikarjun Naula, one of the sacred springs where water is gathered by women for use in Gaura.

\section{DISCUSSION}

The festival of Gaura and the other rituals of the agricultural and spiritual cycle of Malikarjun presented here serve multiple and multifaceted purposes. On the one hand, gods and goddesses are honored and the covenant with the land is reenacted, through celebrating, making offerings and praying for the prosperity of family, community and land. In the specific case of Gaura, the five grains and pulses of the biruda symbolically represent the food of the entire community, and by purifying and offering them the women symbolically purify and offer all the food of the community. Further, culturally important foods are preserved, and local gastronomic identity is enriched, by the incentive to cultivate heirloom crops that are prescribed for use in rituals, such as the kalaun grown for Gaura and the barley grown for Harishayani and Dashain. Simultaneously, the cultivation of landraces has the double benefit of promoting resilience through plant diversity and preserving species adapted to local conditions (Sunderland, 2011; Nabhan, 2014).

The agro-spiritual rituals also have implications for community identity: by participating in Gaura, young brides who have recently married into the community (which is patrilocal) receive their duvdhaga, the womens' sacred thread, which like the festival itself, is unique to far western Nepal. Traditionally, women only become officially integrated into the ceremonial life of the community once they have married and received their duvdhaga by participating in Gaura (men are also not fully integrated into the spiritual community until they have received janai). As such, Gaura not only celebrates and prays for the fertility and health of the community and land, it also affirms the belonging of individuals within the broader spiritual community, and links that belonging with the role of upholding fertility.

As Haider et al. (2020) suggest while describing the ritual use of the red wheat Rashtak in the Pamirs, "It is difficult now to disentangle whether the culture expressed so distinctly through ritual and daily practice exists because of the seed or if the seed exists to serve these cultural practices." This is certainly true in regard to the interpenetration of agriculture and ritual in Malikarjun. However, it is not just the value of these agricultural products to the community that makes them effective in spiritual practice. The cultivation of these products is itself perceived as possessing both a material and a spiritual quality, since it depends on the farmers' labor and knowledge as much as it relies on the elemental and cosmic forces of rain, sun, and soil fertility, which depend on the numinous intercession of gods, goddesses and landscape deities. Seasonal and spiritual cycles are intertwined and inseparable. Thus, through farming, the farmers of Malikarjun participate in something similar to 


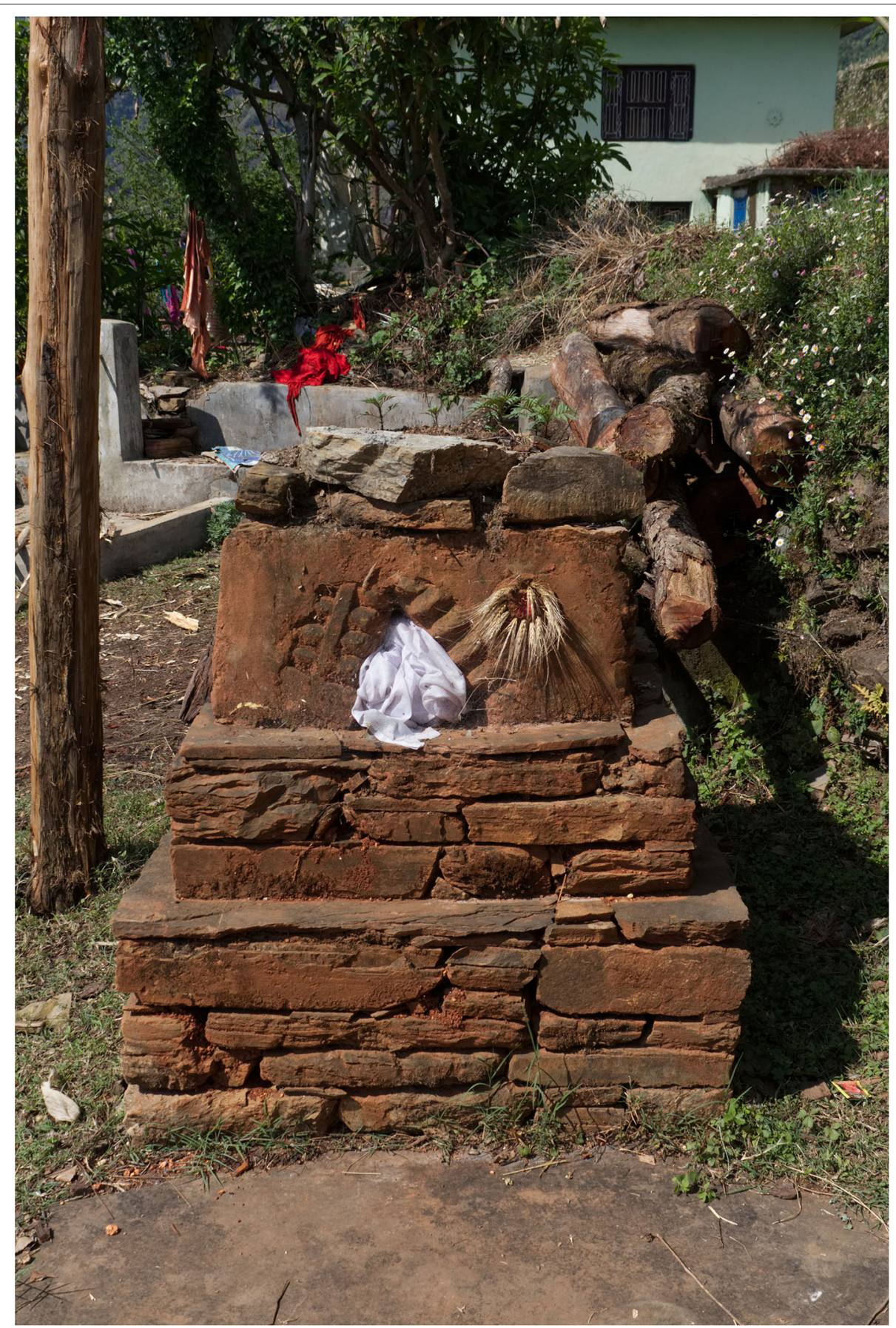

FIGURE 9 | A typical tulsi shrine in a yard in Malikarjun.

what Kimmerer (2013) calls "ceremonies of practical reverence," powerfully pragmatic "acts of reverence," in which manifest and material action has seemingly unmanifest and immaterial effects. When agriculture is understood as a spiritual practice, then the deities who participate in that process are manifest in agricultural products, just as they are also manifest in natural features of the earth like springs, mountains, and caves, as well as in certain specific plants, such as pipal (Ficus religiosa) and tulsi. In this way, the offering of crops completes a cycle by recognizing and returning the energy of life (in the form of food) to its spiritual source.

For anyone intending to engage in, and fully grasp, the practices and the needs of the people of Malikarjun, it is of critical importance that the local food system is understood as the result of the combination of material, spiritual and multispecies relations. From a multispecies perspective, traditional grains and 


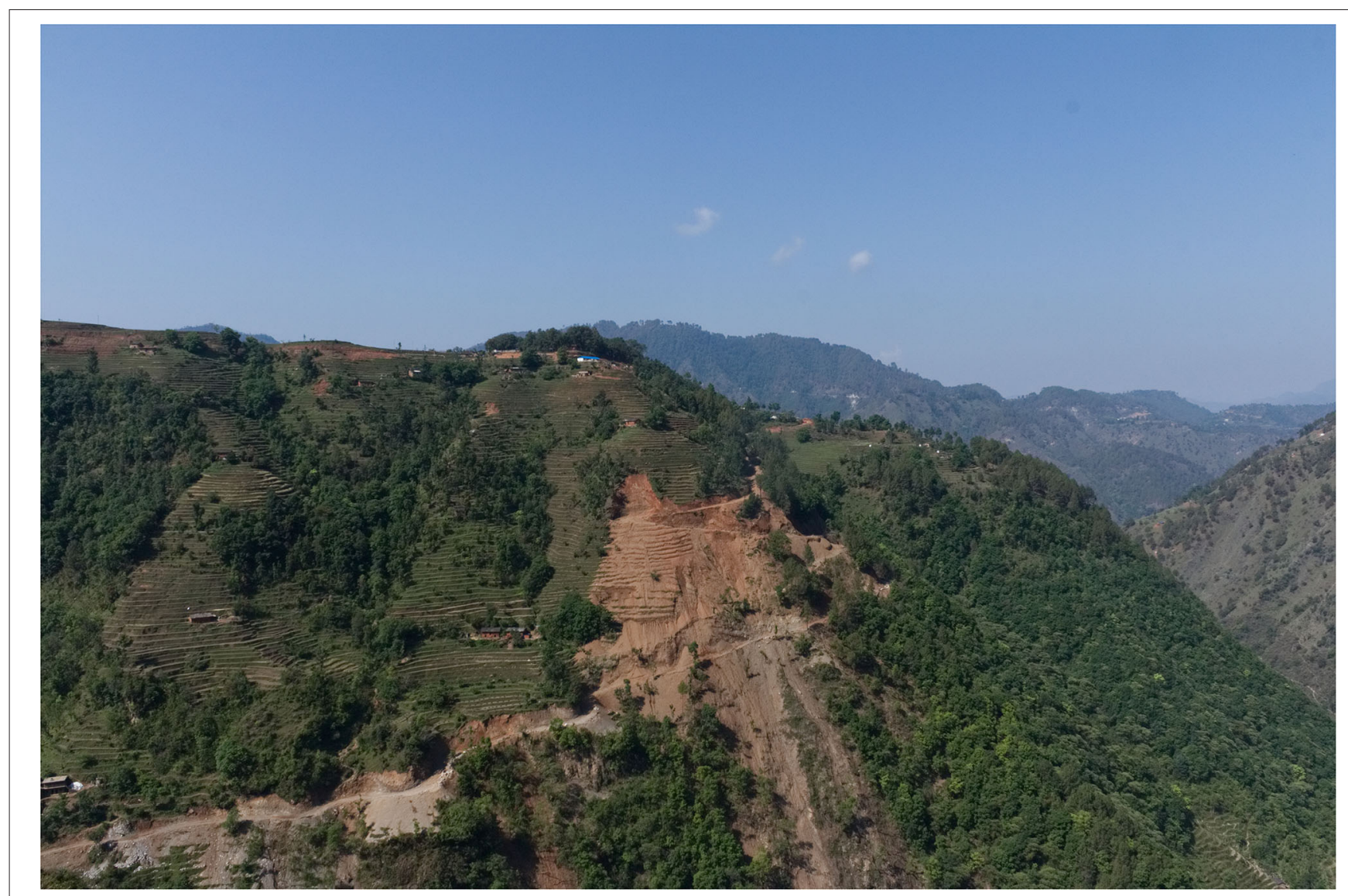

FIGURE 10 | Landslides caused by poorly-implemented road construction in Malikarjun.

pulses like the kalaun pea have evolved over time to play a mediation role in which they allow the covenant between the people the deities, and their divine blessing, to become manifest as nutritious food. Hence, traditional and culturally important foods are spiritually embedded in ways that food produced and purchased outside the community is not. Similarly, in traditional Hopi culture, "...corn is the central bond. Its essence, physically, spiritually, and symbolically, pervades their existence. For the people of the mesas corn is sustenance, ceremonial object, prayer offering, symbol, and sentient being unto itself [...] The connection between the people and the corn is pervasive and deeply sacred. In a remarkable symbiosis between the physical and the spiritual, the Hopi people sustain the corn and the corn sustains Hopi culture" (Wall and Masayesva, 2004).

Road development appears to be one of the main threats to the current food system of Malikarjun. Increased consumption of exogenous and mass produced foods due to better road connections may over time create a disconnect between people and their culturally important foods, and ultimately between people and the land. A decline in local biocultural diversity is a plausible outcome of this disconnect, as rituals and practices may lose salience along with meaning (Pretty et al., 2009). This would likely affect in situ conservation of genetic crop diversity, given that landraces are an invaluable genetic source of disease-resistant material and contribute variation associated with various terroir-dependant flavor profiles, in a context of unpredictability brought about by climate change and cultural transition (Pretty et al., 2009; Sunderland, 2011; Nabhan, 2014). From a food security and quantitative point of view, increased connectivity to distant markets may bring more wealth to individual households, which may in turn improve the general living condition of local families. On the other hand, from the perspective of food sovereignty, opening the local food system to a wider market may result in eroded traditional practices and beliefs; loss of local gastronomic identities, and of landrace diversity in favor of more high-yield or commercially valuable cash crops, with an overall negative impact on local biocultural diversity.

Destruction derived from poorly implemented road development affects households' self-sustenance capacity. In fact, some of the community members lamented lost portions of home-gardens and terraced fields because of poor management of debris from road construction and increased risk of landslides (Figure 10). In the long run, diminished availability of land may cause families to abandon certain crops, hence impacting both plant diversity and diversity in household diet. Another threat to local self-sufficiency is the widespread out-migration in search of work opportunities in the Nepali cities or abroad, 
as decreased workforces seriously impacts families' capacity to meet household needs.

\section{CONCLUSION}

Situated at the intersection of political ecology and ethnobiology, this study demonstrates why spiritual practices should be considered key elements of biocultural diversity. By presenting both agricultural practices and spiritual beliefs, we show how the local food system is embedded within a broader spiritual landscape. We discuss how the covenant between people and the land is constantly reenacted in the yearly festivals and how these provide an incentive to cultivate specific landraces whose use is prescribed in rituals, as in the case of the Gaura festival, where the fertility and well-being of people and land is affirmed through the offering of locally produced heirloom pulses and grains.

Collection and analysis of stories and songs, as well as the investigation of local rituals, constitute crucial methods to reveal the complexity of the agri-food system of Malikarjun's Stories and songs powerfully encapsulate and store history; ecological and traditional knowledge; shared values; ethics. "The songs are sung in the forest, and if people do not go to the forest, they will lose their songs", one of the most knowledgeable local singers, Binda, pointed out during a recording session. Binda succinctly expresses a key issue for many rural and indigenous communities: access to traditional food and the continuation of its linked practices are paramount to the preservation of their knowledge, and vice versa. For communities stories and songs are the seeds of the world to come: alongside selfdetermination and access to land the continuation of traditions and identities depend on them. A great deal of knowledge is lost when people are prevented from being in, or relating to, their homelands in their traditional ways, "gathering plants and animals for food and ceremonies and performing the ceremonies that ensured the prosperity of the earth and its life-forms," (Deloria et al., 1999). We therefore recommend that in the implementation of sustainable development that aims to embody the principles of food sovereignty, local and indigenous ways of knowing should be foundational to all interventions, through the tools of consultation and knowledge co-construction through participatory and communityinformed holistic approaches, and indigenous and decolonizing methodologies (Smith, 1999; Pimbert, 2006; Wilson, 2008; Kovach, 2010; Chilisa, 2012; Drügge, 2016). In particular, we strongly advocate that spiritual practices should be considered key elements of biocultural diversity and the right to food sovereignty, and we urge that they receive greater attention in the academic and policy-making fora, and in all stages of agricultural development.

\section{DATA AVAILABILITY STATEMENT}

The raw data supporting the conclusions of this article will be made available by the authors, without undue reservation.

\section{ETHICS STATEMENT}

Ethical review and approval was not required for the study on human participants, in accordance with the local legislation and institutional requirements. The participants provided their informed consent to participate this study.

\section{AUTHOR CONTRIBUTIONS}

Fieldwork in 2018 was carried out by AG, with assistance from JB. JB translated collected stories and songs. FC was responsible for visual and audio documentation, and the photos and infographics for the manuscript. All authors conducted fieldwork in 2020 and shared the conceptualization, analysis, and writing of this manuscript.

\section{FUNDING}

The research upon which this article is based was funded by a 2019 grant from the Firebird Foundation for the Documentation of Oral Literature and Traditional Ecological Knowledge.

\section{ACKNOWLEDGMENTS}

Don't be fooled by finding our names at the top of this paper. The knowledge, experience, and practices described here belong to the intangible heritage of the people of Malikarjun Rural Municipality. The role of the author is to shape themselves into one minute tube of xylem, to employ the capillary action of the writing process to transport the water of knowledge from where it rests in the roots upward, fighting cultural entropy to bring it at last to the leaves, where it will hopefully diffuse into the atmosphere at large. In this case the roots have names, and it is only through their blessing that you receive this water. Thanks to the chairman of Malikarjun Rural Municipality, Narendra Singh Dhami, the mukhya of Malikarjun Mandir, Rudra Singh Dhami, to Jamuna Devi Dhami, Binda Devi Dhami, and all the others singers, Madan Singh Dhami and the rest of the Music Committee of Chaud Mandir, to the chairpersons and committee members of the community forests, Gopal Singh Dhami, Gyan Singh Dhami, Moti Devi Dhami, Kalyan Singh Dhami, the other Kalyan Singh Dhami and the other Madan Singh Dhami, to our dear friends Lalit Singh Dhami and Lambodar Bist, and to countless others who opened their mouths and doors to let this water flow, too many to name. Thanks also to the partners who laid the groundwork: the intrepid translator Rajendra Bom, the unmatched facilitator Krishna Thagunna and his incredible staff at the Social Awareness and Development Association, Laxmi Bhatta and the International Center for Integrated Mountain Development, Suresh Ghimire at the University of Tribhuvan, Binod Basnet and Hem Paudel at the Kathmandu Herbarium and Rajindra Puri at the University of Kent. And thanks to the mountain that oversees all, who gathers the waters that flow down to the communities below. Jay Malikarjun! 


\section{REFERENCES}

Apgar, J. M., Mustonen, T., Lovera, S., and Lovera, M. (2016). Moving beyond co-construction of knowledge to enable self-determination. IDS Bull. 47:6. doi: 10.19088/1968-2016.199

Barrera-Bassols, N., and Toledo, V. M. (2005). Ethnoecology of the Yucatec Maya: symbolism, knowledge and management of natural resources. J. Latin Am. Geogr. 4, 9-41. doi: 10.1353/lag.2005.0021

Chilisa, B. (2012). Indigenous Research Methodologies. Los Angeles: SAGE Publications.

Coates, K. S. (2004). A Global History of Indigenous Peoples: Struggle and Survival. New York, NY: Palgrave Macmillan. doi: 10.1057/9780230509078

Cochran, F. V., Brunsell, A. N., Cabalzar, A., Van der Veld, P. J., Azevedo, E., Alves Azevedo, R., et al. (2016). Indigenous ecological calendars define scales for climate change and sustainability assessments. Sustain. Sci. 11, 69-89. doi: 10.1007/s11625-015-0303-y/

Declaration of Nyéléni. (2007). Declaration of the International Forum for Agroecology, Nyéléni, Mali: 27 February 2015. Development 58, 163-168. doi: 10.1057/s41301-016-0014-4

Deloria, V. Jr., Scinta, S., Foehner, K., and Deloria, B. (1999). Spirit and Reason: The Vine Deloria, Jr., Reader. Golden: Fulcrum Publishing.

Drügge, A. L. (ed.). (2016). Ethics in Indigenous Research: Past Experiences - Future Challenges. Umeå: Umeå Universitet.

FAO (2019). The State of the World's Biodiversity for Food and Agriculture, eds J. Bélanger and D. Pilling. Rome: FAO Commission on Genetic Resources for Food and Agriculture Assessments.

FAO and UNEP (2020). The State of the World's Forests 2020. Rome: Forests, biodiversity and people.

Gautam, R., Sthapit, B. R., and Shrestha, P. K. (ed.). (2006). "Enhancing the contribution of home garden to on-farm management of plant genetic resources and to improve the livelihoods of Nepalese farmers: lessons learned and policy implications," in Home Gardens in Nepal: Proceeding of a Workshop (Pokhara: LI-BIRD, Bioversity International and SDC).

Gautam, R., Sthapit, B. R., Subedi, A., Poudel, D., Shrestha, P. K., and Eyzaguirre, P. (2008). Home gardens management of key species in Nepal: a way to maximize the use of useful diversity for the well-being of poor farmers. Plant Genet. Resour. 7, 142-153. doi: 10.1017/S1479262108110930

Govindrajan, R. (2015). 'The goat that died for family': animal sacrifice and interspecies kinship in India’s Central Himalayas. Am. Ethnol. 42, 504-519. doi: $10.1111 /$ amet.12144

Gray, J. N. (1979). Keep the hom fires burning: sacrifices in Nepal. Soc. Anal. $1,81-107$.

Håland, E. J. (2009). Women in Greece in relation to year-cycle and life-cycle rituals. Cosmos 25, 35-46. Available online at: http://www.arch.uoa.gr/ fileadmin/arch.uoa.gr/uploads/images/evy_johanne_haland/cosmos25_ry4_ haland.pdf (accessed March 16, 2021)

Håland, E. J. (2012). The ritual year of athena: the agricultural cycle of the olive, girls' rites of passage, and official ideology. J. Religious History 36, 256-284. doi: 10.1111/j.1467-9809.2011.01169.x

Håland, E. J. (2015). Magic in Rituals and Rituals in Magic. The Yearbook of the SIEF (Société Internationale d'Ethnologie et de Folklore) Working Group on the Ritual Year. Innsbruck: Tartu ELM Scholarly Press.

Haider, J. L., Boonstra, J. W., Akobirshoeva, A., and Schlüter, M. (2020). Effects of development interventions on biocultural diversity: a case study from the pamir mountains. Agric. Human Values 37, 683-697. doi: $10.1007 /$ s10460-019-10005-8

Hall, D. (2015). "International agri-food systems," in The Routledge Handbook of Political Ecology, eds T. Perreault, G. Bridge, and J. McCarthy (New York, NY: Routledge), 406-417.

Harvey, D. (2007). A Brief History of Neoliberalism. Oxford: Oxford University Press.

HLPE (2017). Nutrition and food systems. A report by the High Level Panel of Experts on Food Security and Nutrition of the Committee on World Food Security, Rome. Available online at: http://www.fao.org/3/a-i7846e.pdf (accessed March 16, 2021).

Interim Constitution of Nepal 2063. (2007). (Repealed) [Nepal]. Available online at: https://www.refworld.org/docid/46badd3b2.html (accessed March $16,2021)$.
Kassam, K. S., Baumflek, M., Ruelle, M. L., and Wilson, N. (2011). "Human ecology of vulnerability, resilience and adaptation: case studies of climate change from high latitudes and altitudes," in High Latitudes and Altitudes, Climate Change - Socioeconomic Effects, ed H. Kheradmand. Available online at: https:// www.intechopen.com/books/climate-change-socioeconomic-effects/humanecology-of-vulnerability-resilience- and-adaptation-case-studies- of-climatechange-from-high-la (accessed March 16, 2021)

Kassam, K. S., Ruelle, M. L., Samimi, C., Trabucco, A., and Xu, J. (2018). Anticipating climatic variability: the potential of ecological calendars. Hum. Ecol. 46, 249-257. doi: 10.1007/s10745-018-9970-5

Khattri, M. B. (2012). Climate change, millet and ritual relationship with the Magars of Argal, Baglung, Nepal. Dhaulagiri J. Sociol. Anthropol. 6, 107-124. doi: $10.3126 /$ dsaj.v6i0.8481

Kimmerer, R. W. (2012). Searching for synergy: integrating traditional and scientific ecological knowledge in environmental science education. J. Environ. Stud. Sci. 2, 317-323. doi: 10.1007/s13412-012-0091-y

Kimmerer, R. W. (2013). Braiding Sweetgrass: Indigenous Wisdom, Scientific Knowledge, and the Teachings of Plants. Minneapolis: Milkweed Editions.

Kovach, M. (2010). Indigenous Methodologies. Characteristics, Conversations and Contexts. Toronto, ON: University of Toronto Press.

Kunwar, R., and Bussmann, R. W. (2009). Medicinal plants and quantitative ethnomedicine: a case study from Baitadi and Darchula districts, far western Nepal. J. Nat. Hist. Mus. 24, 73-82. doi: 10.3126/jnhm.v24i1. 2244

Kunwar, R. M., Mahat, L., Sharma, L. N., Shrestha, P. K., and Kominee, H., Bussmann,R.W. (2012). Underutilized plant species in Far Western Nepal. J. Mountain Sci. 9, 589-600. doi: 10.1007/s11629-012-2315-8

$\mathrm{Li}, \mathrm{T} . \mathrm{M}$. (2007). The Will to Improve: Governmentality, Development, and the Practice of Politics. Durham: Duke University Press. doi: $10.1515 / 9780822389781$

Mondragón, C. (2004). Of winds, worms and mana: the traditional calendar of the Torres Islands, Vanuatu. Oceania 74, 289-308. doi: 10.1002/j.1834-4461.2004.tb02856.x

Nabhan, G. P. (2014). Food security, biodiversity and human health: ethnobiology as a predictive science. J. Ethnobiol. 34, 7-11. doi: 10.2993/0278-0771-34.1.7

Nadasdy, P. (2005). The anti-politics of TEK: the institutionalization of comanagement discourse. Anthropologica 47, 215-232. Available online at: https://anthropology.cornell.edu/sites/anthro/files/Nadasdy\%202005 \%20Antipolitics\%20of\%20TEK.pdf (accessed March 16, 2021).

Narayan, K. (1997). Sprouting and uprooting of saili: the story of the sacred tulsi in Kangra. Manushi 102, 30-38.

Oli, K. P. and Zomer, R. (2010). Kailash Sacred Landscape Conservation Initiative: Target Area Delineation Report. Kathmandu: ICIMOD.

Orlove, B. S., Chiang, J. C. H., and Cane, M. A. (2002). Ethnoclimatology in the Andes: a cross-disciplinary study uncovers a scientific basis for the scheme andean potato farmers traditionally use to predict the coming rains. Am. Sci. 90, 428-435. doi: 10.1511/2002.33.791

Patel, R. (2007). Transgressing Rights: La Via Campesina’s call for food sovereignty. Femin. Econ. 13, 87-116. doi: 10.1080/13545700601086838

Patel, R. (2009). What does food sovereignty look like? J. Peasant Stud. 36, 663-706. doi: $10.1080 / 03066150903143079$

Pieroni, A., Pawera, L., and Mujtaba Shah, G. (2016). "Gastronomic ethnobiology," in Introduction to Ethnobiology, eds U. P. Albuquerque and R. R. Nóbrega Alves (Heidelberg: Springer), 53-62. doi: 10.1007/978-3-319-28155-1_9

Pimbert, M. (2006). "Transforming knowledge and ways of knowing for food sovereignty and bio-cultural diversity," in Endogenous Development and Bio-Cultural Diversity, the Interplay of Worldviews, Globalization and Locality (Geneva).

Pretty, J., Adams, B., Berkes, F., de Athayde, S., Dudley, N., Hunn, E., et al. (2009). The intersections of biological diversity and cultural diversity: towards integration. Conserv. Soc. 7, 100-112. doi: 10.4103/0972-4923.58642

Prober, S. M., O'Connor, M. H., and Walsh, F. J. (2011). Australian aboriginal peoples' seasonal knowledge: a potential basis for shared understanding in environmental management. Ecol. Soc. 16:212. doi: 10.5751/ES-04023-160212

Rappaport, R. A. (1968). Pigs for the Ancestors. New Haven: Yale University Press.

Rautela, P., and Karki, B. (2015). Weather forecasting: traditional knowledge of the people of Uttarakhand Himalaya. J. Geogr. Environ. Earth Sci. Int. 3, 1-14. doi: $10.9734 / J G E E S I / 2015 / 19016$ 
Rivera-Ferre, M. G. (2018). The agroecology: competing narratives society and intergovernmental Sustain. Food Syst. 42, 666-685.

resignification process of from governments, civil organizations. Agroecol. doi: $10.1080 / 21683565.2018$. 1437498

Salmón, E. (1999). Sharing Breath With Our Relatives: Raramuri Plant Knowledge, Lexicon, and Cognition. [dissertation]. Arizona State University, Phoenix, AZ, United States.

Sarmiento, F., Ibarra, J., Barreau, A., Marchant, C., González, J., Oliva, M., et al. (2019). Montology: a research agenda for complex foodscapes and biocultural microrefugia in tropical and temperate Andes. J. Agric. Food Dev. 5, 9-21. doi: 10.30635/2415-0142.2019.05.2

Smith, L. T. (1999). Decolonising Methodologies: Research and Indigenous Peoples. London: Zed Books and University of Otago Press.

Sunderland, T. C. H. (2011). Food security: why is biodiversity important? Int. Forest. Rev. 13, 265-274. doi: 10.1505/146554811798293908

The Right to Food and Food Sovereignty Act 13, Art. 12(e) of 2075 (2018). Nepal. Available online at: http://extwprlegs1.fao.org/docs/pdf/nep186567.pdf (accessed October 10, 2020).

Van der Ploeg, J. D. (2008). The New Peasantries: Struggles for Autonomy and Sustainability in an Era of Empire and Globalization. London: Earthscan.

Van der Ploeg, J. D. (2010). The peasantries of the twenty-first century: the commoditisation debate revisited. J. Peasant Stud. 37, 1-30. doi: $10.1080 / 03066150903498721$
Wall, D., and Masayesva, V. (2004). People of the corn: teachings in hopi traditional agriculture, spirituality, and sustainability. Am. Indian Q. 28, 435-453. doi: 10.1353/aiq.2004.0109

White, B., Borras, M. S., Hall, R., Scoones, I., and Wolford, W. (2012). The new enclosures: critical perspectives on corporate land deals. J. Peasant Stud. 39, 619-647. doi: 10.1080/03066150.2012.691879

Wilson, S. (2008). Research is Ceremony. Black Point: Fernwood Publishing.

Wyndham, F. S. (2009). Spheres of relations, lines of interaction: subtle ecologies of the Rarámuri Landscape in Northern Mexico. J. Ethnobiol. 29, 271-295. doi: 10.2993/0278-0771-29.2.271

Zomer, R., and Oli, K. P. (ed.). (2011). Kailash Sacred Landscape Conservation Initiative: Feasibility Assessment Report. Kathmandu: ICIMOD.

Conflict of Interest: The authors declare that the research was conducted in the absence of any commercial or financial relationships that could be construed as a potential conflict of interest.

Copyright $\odot 2021$ Castagnetti, Bhatta and Greene. This is an open-access article distributed under the terms of the Creative Commons Attribution License (CC BY). The use, distribution or reproduction in other forums is permitted, provided the original author(s) and the copyright owner(s) are credited and that the original publication in this journal is cited, in accordance with accepted academic practice. No use, distribution or reproduction is permitted which does not comply with these terms. 